\title{
A Virtual PV Systems Lab for Engineering Undergraduate Curriculum
}

\author{
Emre Ozkop and Ismail H. Altas \\ Department of Electrical and Electronics Engineering, Karadeniz Technical University, 61080 Trabzon, Turkey \\ Correspondence should be addressed to Emre Ozkop; emreozkop@hotmail.com
}

Received 28 October 2013; Accepted 4 February 2014; Published 13 March 2014

Academic Editor: Adel M. Sharaf

Copyright ( 2014 E. Ozkop and I. H. Altas. This is an open access article distributed under the Creative Commons Attribution License, which permits unrestricted use, distribution, and reproduction in any medium, provided the original work is properly cited.

\begin{abstract}
Design and utilization of a Virtual Photovoltaic Systems Laboratory for undergraduate curriculum are introduced in this paper. The laboratory introduced in this study is developed to teach students the basics and design steps of photovoltaic solar energy systems in a virtual environment before entering the field. The users of the proposed virtual lab will be able to determine the sizing by selecting related parameters of the photovoltaic system to meet DC and AC loading conditions. Besides, the user will be able to analyze the effect of changing solar irradiation and temperature levels on the operating characteristics of the photovoltaic systems. Common DC bus concept and AC loading conditions are also included in the system by utilizing a permanent magnet DC motor and an RLC load as DC and AC loading examples, respectively. The proposed Virtual Photovoltaic Systems Laboratory is developed in Matlab/Simulink GUI environment. The proposed virtual lab has been used in Power Systems Lab in the Department of Electrical and Electronics Engineering at Karadeniz Technical University as a part of undergraduate curriculum. A survey on the students who took the lab has been carried out and responses are included in this paper.
\end{abstract}

\section{Introduction}

As the utilization of photovoltaic (PV) solar energy systems gain importance day by day, training seminar sessions, short courses, and certificate programs are offered by companies in order to close the gap of the experienced professionals in designing and utilizing the PV systems. As a part of encouraging the use of renewable energy sources, government in many countries recommend schools and universities to include the renewable energy sources such as solar and wind in their curriculum. Modeling, analyzing, and designing of PV solar energy systems are taught in a course called Design of Low Voltage Power Systems and a set of PV experiments are included in Power Systems Lab in the Department of Electrical and Electronics Engineering at Karadeniz Technical University, Turkey. In order to teach the modeling and characteristic behaviors of the PV arrays, a virtual PV Systems Lab is developed and offered to be used by the students as a part of undergraduate curriculum.

The changes and developments such as globalization, economic crisis, and technological innovations involve reconsidering education system curriculum [1]. In conventional education system, courses have been based on the principal of printed word and blackboard [2]. Studying mainly mathematics and basic concepts to understand the dynamic system responses causes students to be less interested in essential subject. If the students are provided with various ways to reach learning sources of information, which is one of the flexible education aims, classical education based on textbooks and chalkboards becomes time consuming and insufficient in completion realize the dynamic system responses, nowadays $[3,4]$.

While students attain theoretical knowledge in the classroom, practical knowledge and experiences are given in laboratories [2]. Laboratory is an integral part of undergraduate studies particularly in engineering education [1]. Laboratory works give students the ability to design and conduct experiments, analyze and interpret data, design a system and component, and develop social and team work skills and also increase learning efficiency in engineering education $[2,5,6]$. There are many studies to improve engineering students' skills [7].

Even though students get theoretical background very well in detail in classroom, and they are provided lab manuals 
to study and become familiar with the experiments they are going to do in laboratory, they always face difficulties in practice when it comes to setting up and performing the actual experimental tests. It has been always a task to have the students gain the ability to turn the theoretical knowledge into practical reality. In particular, the engineering students should be able to combine the theory with the practice. Course laboratories in schools and universities are the first and important places for the students to put their knowledge into practice. However, every student does not have the chance to use the labs for practicing before the lab hour for the course starts. Every student does not have the income to establish his/her own high cost test laboratory for checking the experiment designed to be performed.

Experimental setup has a high cost and also lacks doing experiments again and again in nonlinear range $[8,9]$. There are generally limited laboratory equipments, space, time period, and danger for laboratory experiments such that it is not possible for the students to do an experiment alone in laboratory. Besides, the increasing number of the students every year becomes a heavy burden to departments with laboratories $[1,5]$. Consequently, either the number of experiment groups or the number of students in the experiment groups must be increased. In any case more teaching assistants and lab equipments are required to deliver the experiments efficiently. Otherwise, the students will not be able to learn and interpret effectively in the experiments [1,9-11]. If the required conditions for a high quality or a normal laboratory are not provided, then the practical experiment part of the education will be insufficient resulting in inexperienced graduates deprived of scientific knowledge and abilities [3]. Insufficient laboratory conditions and experiments decrease the education quality and result in the presence of incompetent graduates with less ability [1]. Therefore, new alternatives are always the challenge to keep the laboratory experiments and the practical abilities of the graduates high. That is where the virtual laboratories become important. Virtual laboratories are software based simulators of the actual systems and require only the computers to be performed.

Since computer prices decrease and it is possible to find easily variable versatile software programs, computeraided education has become a part of both classroom and laboratory experiments [12]. With new technological innovations, computers have been benefited as auxiliary equipments and teaching tools in many universities [13]. The uses of computers make a positive impact in lectures and laboratory work and also contribute economically towards mitigating the education cost [1]. A lack of concentration lessons and students' performances are positively affected with computer applications as compared to hands-on labs alone [1]. Computer based virtual lab software has been used as a part of education tools to develop the students' comprehension in both theoretical and experimental topics [14]. When the comparison is made between the handson experiments and the virtual learning experiments, it is obvious that the virtual one provides a flexible, time invariant and location free learning environment, to perform many different and less costly experiments. Moreover, each student can realize more complex and extensive experiments alone so that self-learning potential of the students is brought to forward [14]. The virtual laboratory enables easy interaction for students and has flexible parameter variations for ongoing experiments and gives prominent understanding into experimental dynamics [6]. Virtual learning environments give students opportunity to establish a connection from theoretical concepts to practical applications [14]. The virtual learning environments corroborate students to design experiments based on the concept they are studying and also provide immediate graphical feedback. It is obvious that the virtual learning has a comprehensive and interactive environment [1]. Nowadays, many universities and institutions have applied virtual laboratories. A virtual laboratory can be utilized by the means of combining both physical experiments and numerical simulations [14].

Commercially available software packages have been progressively used for educational purposes as the high performance and cost efficient computers developed [15, 16]. There are many different software packages developed using independent language platforms. These virtual labs are usually developed for certain purposes and are not expandable for more detailed experiments. On the other hand, there are some software platforms that are suitable for developing virtual laboratories. MATLAB is one of these software platforms used by a great number of universities throughout the world and it might be the better choice since engineering students are generally acquainted with MATLAB $[2,12,16-19]$. The user can design, develop, expand, simulate, analyze, and visualize data with MATLAB and its toolbox Simulink software $[16,20]$.

Graphical user interface (GUI) ability of Matlab/Simulink software environment is used to develop the Virtual PV Systems lab introduced in this paper. Mathematical model of the PV cell and PV array given in [21] is modified and used in this study. The Virtual PV Systems lab provides the measurement and analysis of PV arrays $I-V$ and $P-V$ characteristics at constant and variable solar irradiation and temperature levels. The user is able to modify the number of panels in series and in parallel so that a desired array combination can be designed to match the load requirements. The virtual lab also includes a power electronics converter to give the opportunity of controlling the output voltage of the PV arrays. A permanent magnet DC motor is also used as a load to analyze the operational characteristics of the PV system under variable load. The proposed virtual lab has been used in Power Systems laboratory in the Department of Electrical and Electronics Engineering at Karadeniz technical University, Turkey, and the responses from the students are evaluated.

\section{System Architecture}

The Virtual PV Systems Lab (VPVSL) is intended to be used as an auxiliary supporting virtual environment for the actual PV System lab. The idea behind the combination of the virtual and actual labs is based on student outcome requirements described by ABET as A-K engineering education criteria's 


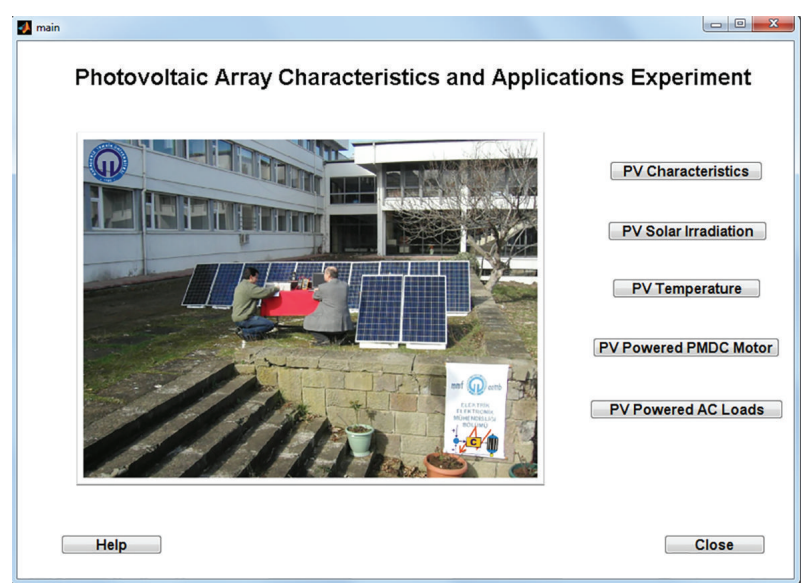

Figure 1: The main menu of VPVSL.

[22]. Two of the A-K criteria's highlight the importance of the "ability to design and conduct experiments as well as to analyze and interpret data" and "ability to design a system, component, or process to meet desired needs within realistic constraints..." [22]. In order to have the students gain the ability of designing and conducting experiments on PV systems, proposed VPVSL is developed.

The lab is conducted in the following order.

(i) Define the size and operational specifications of the system.

(ii) Determine the values of required parameters and enter them into the VPVSL software using the user data interfacing windows shown in Figures 1, 2, 3, 4, 5 , and 6 .

(iii) Select the configuration (DC or AC load) type to be used.

(iv) Obtain $I-V$ and $P-V$ characteristics of the PV array for various solar irradiation and temperature levels and analyze them.

(v) Obtain the optimum operating power points for various operating conditions.

(vi) Run the VPVSL, record the results, and analyze them.

Students write their lab reports based upon the data they obtained from the VPVSL and keep them to compare with those obtained using actual PV system lab. The use of the VPVSL before the actual lab is that students get to know the PV system and its operational characteristics so that they become familiar with the designing steps and characteristics. Therefore, they have no difficulties when performing the real time PV system experiments as well as designing real time PV system applications. The VPVSL software is developed using Matlab/Simulink GUI environment. Figure 1 shows the first user interfacing screen, which is also called the main window. This window includes the following five modules, which are explained in the next sections:

(1) PV characteristics,

(2) PV solar irradiation,
(3) PV temperature,

(4) PV powered PMDC motor,

(5) PV powered AC loads.

2.1. Module 1: PV Array Characteristics. This module uses the PV cell model described by

$$
V_{C}=\frac{A k T_{C}}{e} \ln \left(\frac{I_{\mathrm{ph}}+I_{0}-I_{C}}{I_{0}}\right)-R_{S} I_{C},
$$

where $A$ is curve fitting constant used in solar cell $I-V$ characteristics, $e$ is electron charge, $k$ is Boltzmann constant, $I_{C}$ is the cell output current, $I_{\mathrm{ph}}$ is photocurrent, $I_{0}$ is the reverse saturation current of diode, $R_{S}$ is series resistance of cell, $T_{C}$ is reference cell operating temperature, and $V_{C}$ is the cell output voltage. The cell parameters values used in this study are given in the Appendix. All these cell parameters and modelling details are given in [21]. The module runs the characteristic equation in the back and offers the user to enter the simulation parameters that are needed to obtain the PV array current-voltage and power-voltage characteristics under certain solar irradiance and ambient temperature. The user interface window of Module 1 is shown in Figure 2. Number of cells in series $\left(N_{S}\right)$ in a branch and number of parallel connected series branches $\left(N_{P}\right)$ are the main inputs for sizing the PV array to get the required power. Solar irradiation and ambient temperature are the other two inputs in order to obtain the PV array characteristics for these light and temperature levels.

Students are able to resize the PV array to meet the load requirements and obtain the $I-V$ and $P-V$ characteristics. After entering the panel configuration and external condition, the module returns the characteristics along with the maximum power point operating quantities. This module teaches the student how the resizing affect the power output of a PV array under constant solar irradiation and ambient temperature.

2.2. Module 2: Solar Irradiation Effects on PV Array Characteristics. This module shows how the changes in solar irradiation affect the output current and voltage and the power of a PV array. The inclusion of the effects of the changes in solar irradiation level in PV array modeling is described by the following equations, which are discussed in $[23,24]$ :

$$
\begin{gathered}
C_{T V}=1+\beta_{T}\left(T_{a}-T_{x}\right), \\
C_{T I}=1+\frac{\gamma_{T}}{S_{C}}\left(T_{x}-T_{a}\right), \\
C_{S V}=1+\beta_{T} \alpha_{S}\left(S_{x}-S_{C}\right)=1+\beta_{S}\left(S_{x}-S_{C}\right), \\
C_{S I}=1+\frac{1}{S_{C}}\left(S_{x}-S_{C}\right)=1+\gamma_{S}\left(S_{x}-S_{C}\right), \\
\Delta T_{C}=\alpha_{S}\left(S_{x}-S_{C}\right), \\
V_{C X}=C_{T V} C_{S V} V_{C}, \\
I_{\mathrm{ph} x}=C_{T I} C_{S I} I_{\mathrm{ph}},
\end{gathered}
$$




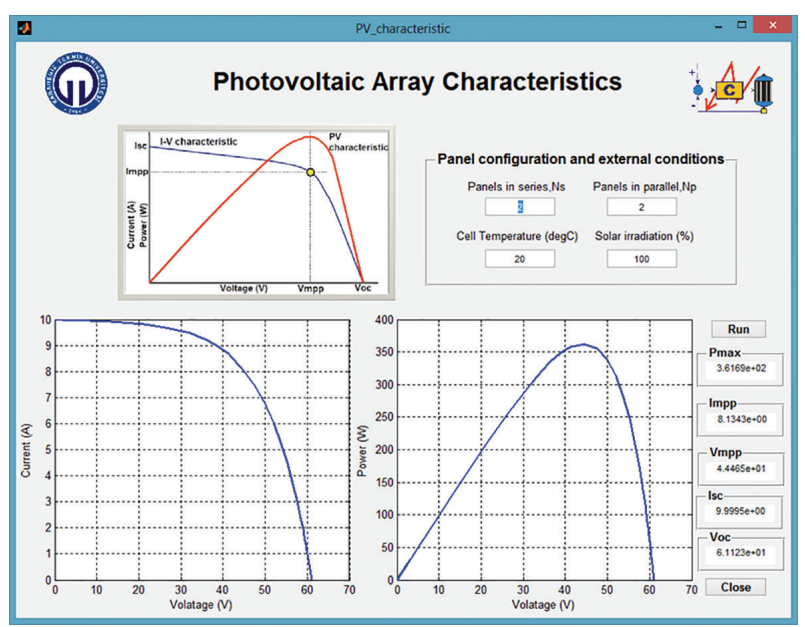

FIGURE 2: The photovoltaic array characteristics interface.

where $T_{a}$ is the reference ambient temperature, $S_{C}$ is the reference solar irradiation, and $T_{x}$ and $S_{x}$ are the current values of the ambient temperature and solar irradiation, respectively. $\beta_{T}$ and $\gamma_{T}$ are constants representing the effect of temperature on PV cell voltage and current, respectively. The constant $\alpha_{S}$ represents the slope of the change in the cell operating temperature due to a change in the solar irradiation. Constants $\beta_{S}$ and $\gamma_{S}$ represent effect of the solar irradiation on cell voltage and photocurrent, respectively. Equations (2) and (3) yield the temperature gain parameters $C_{T I}$ and $C_{T V}$ for current and voltage, respectively, while (4) and (5) give the solar irradiation gain parameters $C_{S I}$ and $C_{S V}$ for current and voltage. These gain parameters are used in (7) and (8) in order to update the values of PV cell voltage and current to the new cell voltage and new photocurrent under new cell temperature $T_{x}$ and solar irradiation $S_{x}$. Temperature constants $\left(\beta_{T}\right.$ and $\left.\gamma_{T}\right)$ and solar irradiation constants $\left(\alpha_{S}, \beta_{S}\right.$, and $\gamma_{S}$ ) are obtained experimentally for the PV cell type used in both simulation and test studies. Since the PV cell types and the properties are assumed to be the same in a PV panel, these constants may also be obtained by running the similar tests with the PV panels used. After recording the reference values at known temperature and solar irradiation levels, the same quantities are measured at another known temperature and solar irradiation level and the differences are compared. The same test may be repeated for a few times at different temperature and solar irradiation levels for better correlation. Then (2) to (8) are used backwards to obtain the constant parameters used in these formulas. After this process, the obtained constant can only be used for the models of the PV cells that are used in the testing.

As shown in Figure 3, panel configuration and cell temperature are given as the constant inputs besides the four different solar irradiation values. After running the module, the students get four different normalized $I-V$ and $P-V$ curves, one for each solar irradiation. The module also returns the maximum power point operating power, voltage, and current values $P_{\max }, I_{\mathrm{mpp}}$, and $V_{\mathrm{mpp}}$ for all four solar irradiation levels.

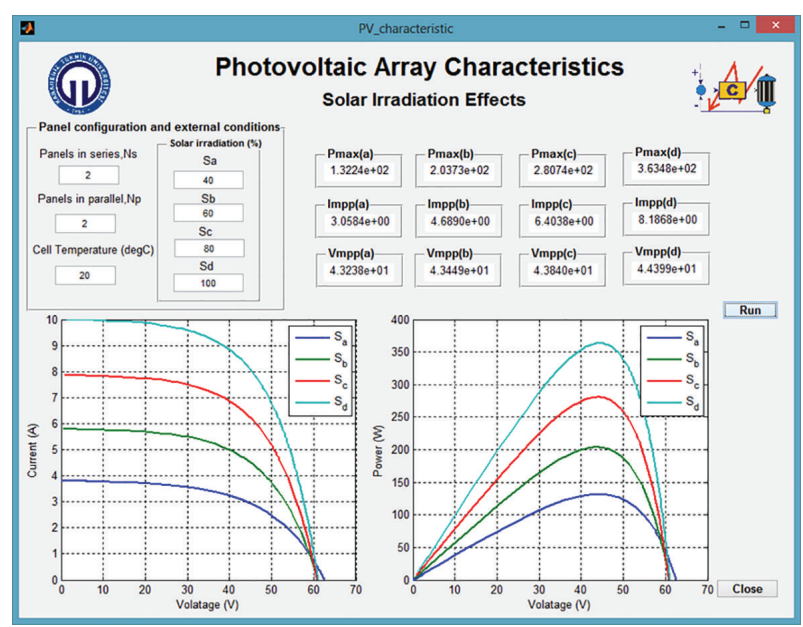

FIgURE 3: The photovoltaic array solar irradiation interface.

It is clear that this module gives a good understanding and interfacing to the student to analyze the effects of variable solar irradiation levels on PV array characteristics.

\subsection{Module 3: Temperature Effects on PV Array Character-} istics. This module uses the same equation set (2) to (8) given in previous section about Module 2. The students are able to configure the array and analyze the effects of variable temperature on PV array characteristics while the solar irradiation is kept constant. Figure 4 shows the user interface screen for Module 3. After running the module, the students get four different normalized $I-V$ and $P-V$ curves, one for each temperature level. The module also returns the maximum power point operating power, voltage, and current values $P_{\text {max }}, I_{\text {mpp }}$, and $V_{\text {mpp }}$ for all four temperature levels. It is clear that this module gives a good understanding and interfacing to the students to analyze the effects of variable temperature on PV array characteristics.

2.4. Module 4: PMDC Motor Load Fed from PV Array. Once the students learn and understand the PV array characteristics under different environmental conditions, they can continue the simulation based experiments by starting to feed the loads. The first load in VPVSL is a permanent magnet DC (PMDC) motor. This scheme includes a PV array with the required voltage and power configuration, a filter circuit to eliminate the discontinuities in current, a PID controlled DC/DC chopper, a PID controller, and a PMDC motor. Figure 5 shows the user interfacing windows and the connection diagram of the PV powered PMDC motor scheme. The user interface scheme has PV array data, motor data, and PID controller data as three input areas and four graphic windows as the output areas. Time response of the PMDC motor speed, PMDC motor voltage, and PV array $I-V$ and $P-V$ characteristics under loading conditions are plotted in the output section. Since a maximum power point tracker (MPPT) is not added to the scheme, the operating power may not be at its maximum value and may be changed as the reference voltage is changed by the user. An MPPT may be 


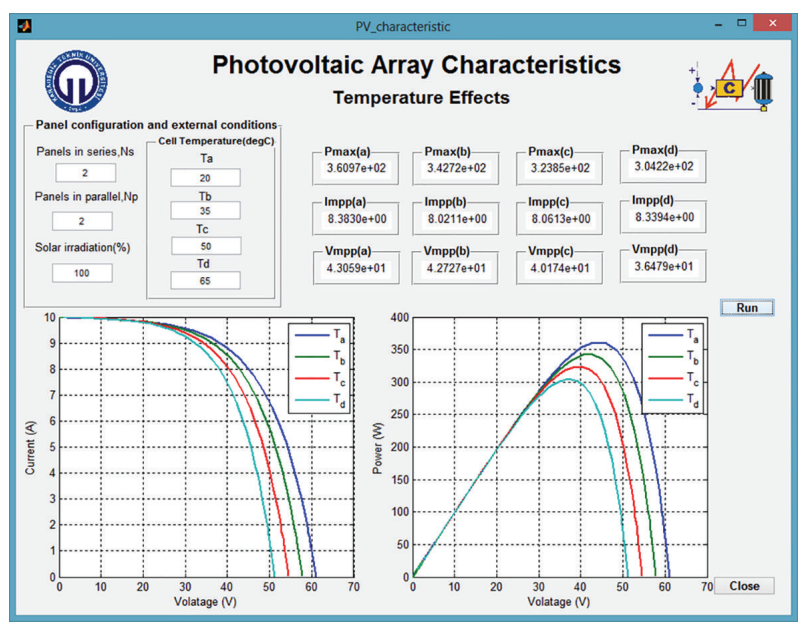

FiguRE 4: The photovoltaic array temperature interface.

considered to be added to the scheme for a more complete simulation model.

This module gives the students an opportunity of understanding DC load operation and control. A PID controller is employed to operate the PMDC motor at a constant voltage while the temperature and solar irradiation levels of the PV array change. The module can be simulated without and with the controller to see the effects of the changes in sunlight level. In order to have a constant motor speed, the voltage to the motor must be kept constant. Therefore, the constant speed means constant DC voltage, which may be assumed as a DC bus used to collect the DC power from different sources in distributed generation networks. Therefore, this module also teaches the common DC bus concept with the control in practice.

2.5. Module 5: AC Loads Fed from PV Array. The DC chopper in previous module is replaced by a three-phase inverter in order to obtain a three-phase AC voltage with nominal voltage and constant frequency. As shown in user interface screen of Module 5 in Figure 6, this module includes six input areas, which are used for panel configuration, RLC AC load, filter parameters, RL DC load, controller parameters, and a three-phase isolation transformer.

There are six output plots in the user window. The students are able to plot and observe the voltage at the output terminals of the inverter, the voltage of the PV array under load, $I-V$ characteristics of the array under loading, the AC voltage at load terminals, PV array current under load, and $P-V$ characteristics of the panel under loading conditions. A DC load is connected before the inverter in order to initiate the operation of the PV array.

\section{Simulation Results}

This section gives the results from the virtual experiments done to test the proposed VPVSL. Five modules described above are tested in given order. First the PV array characteristics, then the effects of the solar irradiation, the effects

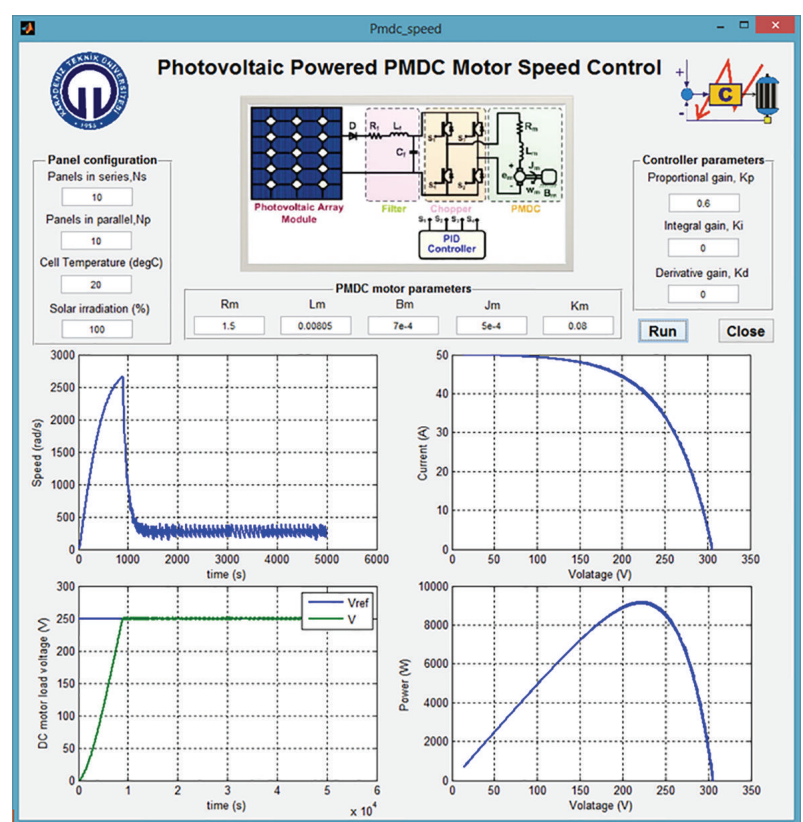

FIGURE 5: The PV powered PMDC motor interface.

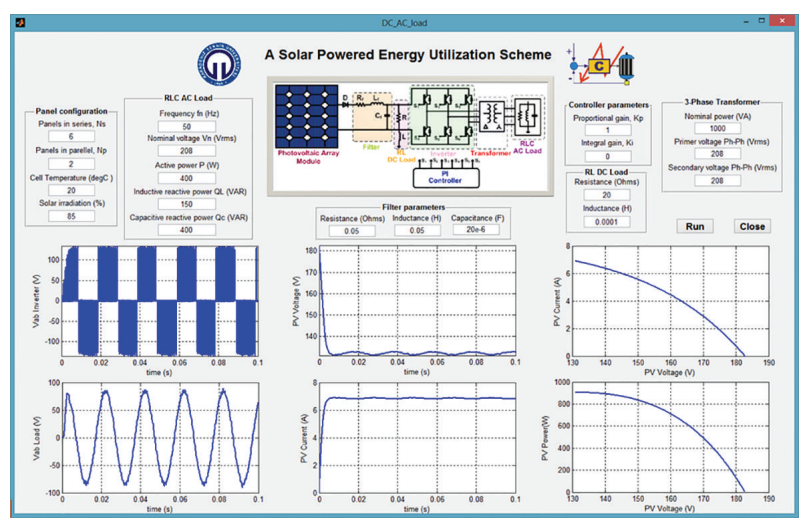

FIgURE 6: The PV powered AC loads interface.

of temperature, DC load operation, and finally the AC load operation are tested.

3.1. PV Array Characteristics. The GUI screen given in Figure 2 for Module 1 is used to perform the tests for PV array characteristics. The system is simulated for eight different PV array configurations under reference temperature and solar irradiation levels, which are $20^{\circ} \mathrm{C}$ and $100 \mathrm{~mW} / \mathrm{cm}^{2}$. The array configurations and corresponding maximum power point operating values are given in Table 1 for a sample case study. These sets of experiments give the students an insight look at the design of PV systems in terms of sizing.

Results from the sample case study are depicted in Figure 7. The size of the PV array is changed by different combinations of series and parallel connected PV panels, and the resultant operating parameters are recorded from each case. The sizing effect on open circuit voltage $\left(V_{\mathrm{oc}}\right)$, short circuit current $\left(I_{\mathrm{sc}}\right)$, maximum power $\left(P_{\max }\right)$, maximum power point current $\left(I_{\mathrm{mpp}}\right)$, and maximum power point 


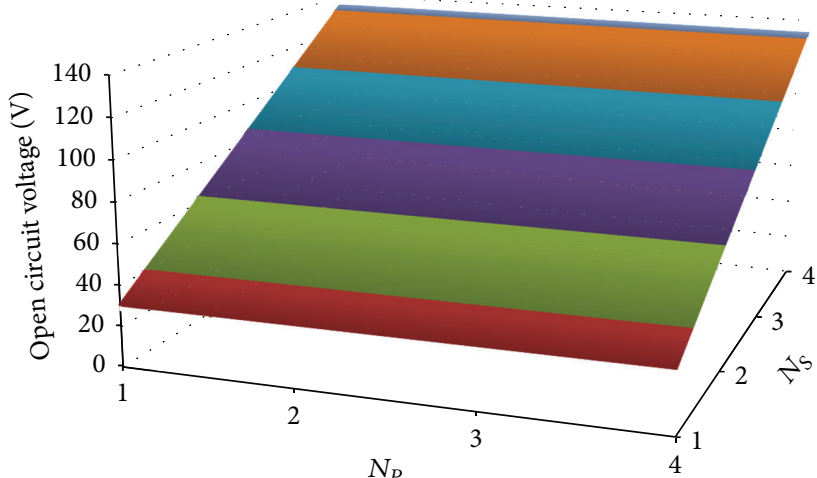

$\begin{array}{ll}\square 120-140 & \square 40-60 \\ \square 100-120 & \square 20-40 \\ \square 80-100 & \square 0-20 \\ \square 60-80 & \end{array}$

(a) Open circuit voltage surface

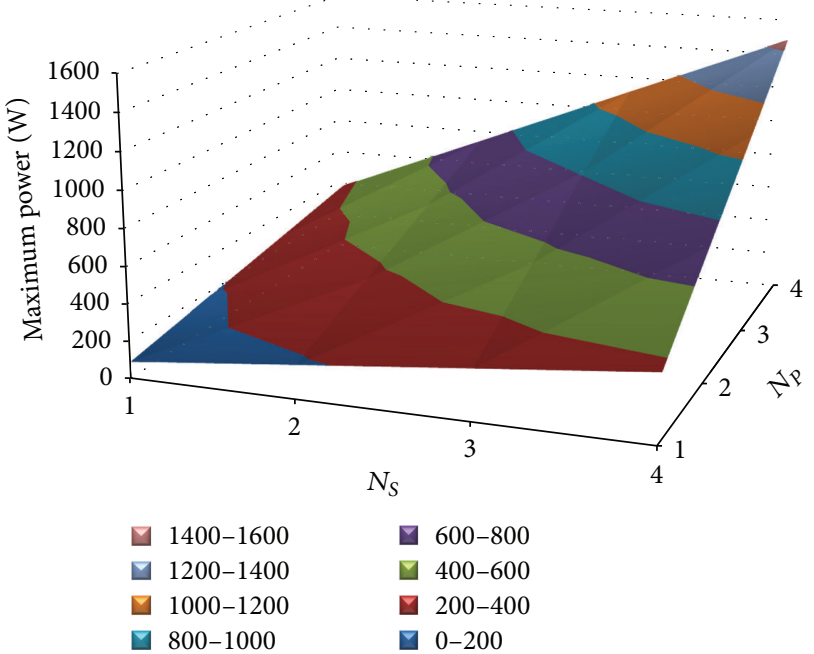

(c) Maximum power surface

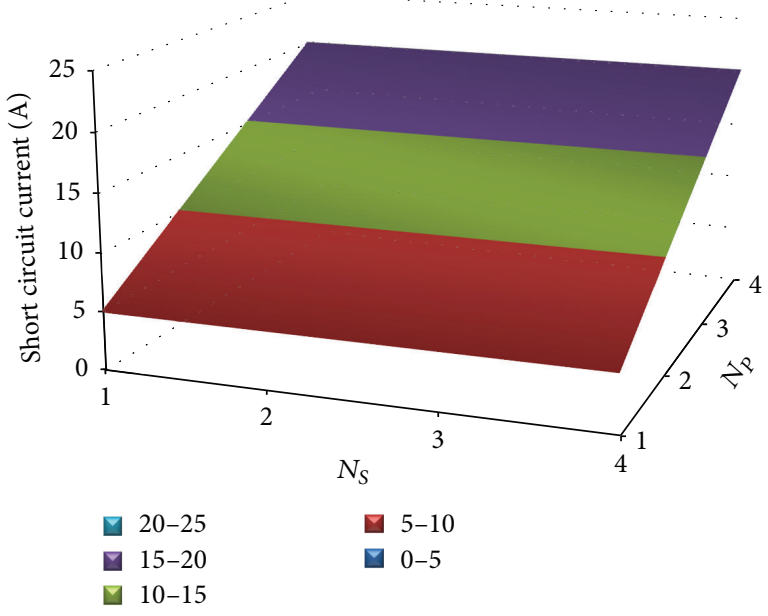

(b) Short circuit current surface

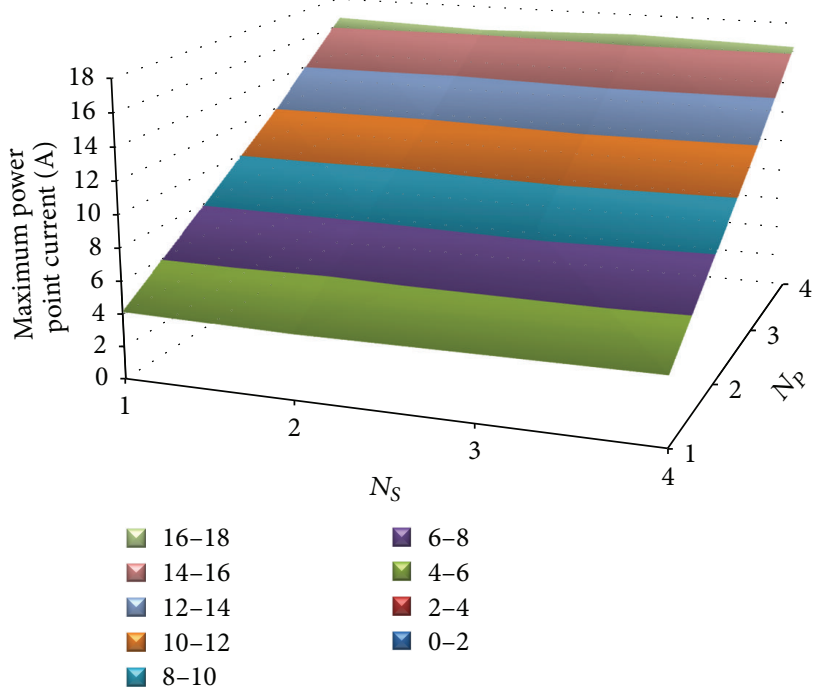

(d) Maximum power point current surface

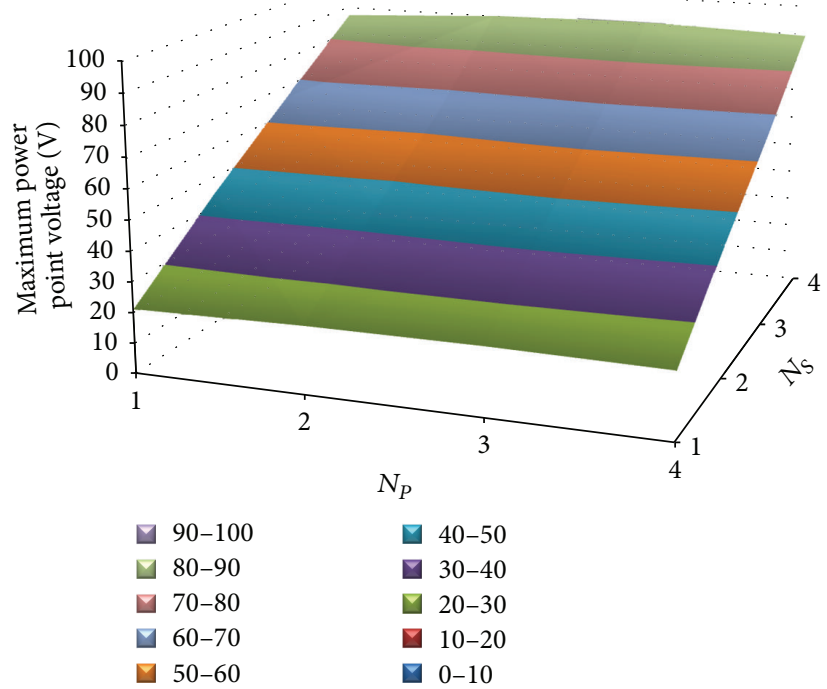

(e) Maximum power point voltage surface

FiguRE 7: The sizing effects on the array characteristics at reference temperature and solar irradiation levels. (a) Open circuit voltage surface, (b) short circuit current surface, (c) maximum power surface, (d) maximum power point current surface, and (e) maximum power point voltage surface. 
TABLE 1: The PV array characteristics experiment parameters and outputs.

\begin{tabular}{|c|c|c|c|c|c|c|c|c|}
\hline Case & I & II & III & IV & $\mathrm{V}$ & VI & VII & VIII \\
\hline$N_{S}$ & 1,000 & 2,000 & 3,000 & 4,000 & 1,000 & 1,000 & 1,000 & 2,000 \\
\hline$N_{P}$ & 1,000 & 1,000 & 1,000 & 1,000 & 2,000 & 3,000 & 4,000 & 2,000 \\
\hline$P_{\max }(\mathrm{W})$ & 90,147 & 180,90 & 271,38 & 361,00 & 180,80 & 271,52 & 362,48 & 361,69 \\
\hline$I_{\text {mpp }}(\mathrm{A})$ & 4,210 & 4,043 & 4,121 & 4,186 & 8,077 & 12,037 & 16,533 & 8,134 \\
\hline$V_{\text {mpp }}(\mathrm{V})$ & 21,416 & 44,741 & 65,803 & 86,234 & 22,384 & 22,558 & 21,925 & 44,465 \\
\hline$I_{\mathrm{sc}}(\mathrm{A})$ & 4,998 & 5,000 & 5,000 & 5,000 & 9,996 & 14,992 & 19,985 & 9,999 \\
\hline$V_{\mathrm{oc}}(\mathrm{V})$ & 30,561 & 61,123 & 91,664 & 122,25 & 30,561 & 30,561 & 30,561 & 61,123 \\
\hline Case & IX & $\mathrm{X}$ & $\mathrm{XI}$ & XII & XIII & XIV & XV & XVI \\
\hline$N_{S}$ & 2,000 & 2,000 & 3,000 & 3,000 & 3,000 & 4,000 & 4,000 & 4,000 \\
\hline$N_{P}$ & 3,000 & 4,000 & 2,000 & 3,000 & 4,000 & 2,000 & 3,000 & 4,000 \\
\hline$P_{\max }(\mathrm{W})$ & 542,05 & 723,39 & 541,61 & 813,81 & 1085,50 & 723,72 & 1085,1 & 1446,7 \\
\hline$I_{\mathrm{mpp}}(\mathrm{A})$ & 11,914 & 16,262 & 8,364 & 12,233 & 16,550 & 8,118 & 12,042 & 16,332 \\
\hline$V_{\mathrm{mpp}}(\mathrm{V})$ & 45,496 & 44,483 & 64,751 & 66,524 & 65,592 & 89,146 & 90,109 & 88,582 \\
\hline$I_{\mathrm{sc}}(\mathrm{A})$ & 14,998 & 19,998 & 10,002 & 15,002 & 20,001 & 10,001 & 15,001 & 20,003 \\
\hline$V_{\mathrm{oc}}(\mathrm{V})$ & 61,123 & 61,123 & 91,684 & 91,684 & 91,684 & 122,25 & 122,25 & 122,25 \\
\hline
\end{tabular}

TABle 2: Maximum power point surface, $P_{\max }(\mathrm{W})$, at a fixed configuration.

\begin{tabular}{lccccc}
\hline$N_{s}=2$ & & \multicolumn{3}{c}{$T_{x}$} \\
$N_{p}=2$ & & -20 & 0 & 20 & 40 \\
\hline \multirow{4}{*}{80} & 316 & 298 & 280 & 261 \\
& 100 & 410 & 386 & 362 & 337 \\
$S_{x}$ & 120 & 512 & 481 & 451 & 418 \\
& 140 & 618 & 581 & 543 & 505 \\
& 160 & 733 & 688 & 642 & 595 \\
& 180 & 850 & 797 & 745 & 691 \\
& 200 & 977 & 915 & 853 & 790 \\
\hline
\end{tabular}

voltage $\left(V_{\mathrm{mpp}}\right)$ are shown in Figure 7 by surface plots where solar irradiation and temperature levels are kept constant. The surfaces in Figure 7 are called the Design Surfaces and used as the base load power matching in design process. These design surfaces can be extended to include the effects of the changes in solar irradiation and temperature levels. Therefore these surfaces can be converted into dynamic design surfaces so that both the maximum power operating point values can be tracked when the environmental conditions are changed and the configuration switching for load power matching can be done.

3.2. Solar Irradiation and Temperature Effects. Simulation results of Modules 2 and 3 of VPVSL are discussed in this section. The students get the $I-V$ and $P-V$ curves of the PV array at different solar irradiation and temperature levels for a fixed configuration by keeping $N_{S}$ and $N_{P}$ unchanged. For the sample case study, the array configuration is set to $N_{S}=2$ and $N_{P}=2$.

First, operating temperature is assumed to be constant in Module 2 and only the solar irradiation is changed. Therefore, tests from Module 2 give the characteristics for changing sunlight levels at constant temperature as given in Figure 8. Solar irradiation is assumed to be constant in Module 3 and only the temperature is changed to see the effects of temperature on the PV array characteristics. The results from Module 3 are given in Figure 9.

Both Module 2 and Module 3 show that the generated power from the PV array changes when temperature and solar irradiation levels change. Therefore the recordings from these two modules can be combined to yield the maximum power generated by the PV array at different pairs of solar irradiation and temperature as given in Table 2.

A similar table can also be obtained easily for maximum power point current and voltages. However, for the sake of using optimum number of pages, these tables are not given here. The plots of the maximum power points, maximum power point operating currents, and maximum power point operating voltages are given in Figure 10 instead.

The results from Module 2 and Module 3 are evaluated together in order to see the solar irradiation and temperature effects at the same time. The combination of the results from these two modules enables the user to obtain maximum power points, maximum power point operating currents, and maximum power point operating voltages at different solar irradiation and temperature levels. Threedimensional surface plots of these maximum power point quantities are shown in Figure 10. Actually these surfaces are used as dynamic design surfaces as expressed before. These surfaces are called the dynamic design surfaces because the maximum power operating points move on these surfaces when the solar irradiation and temperature levels change as unpredictable and uncontrolled input variables. The users of the VPVSL or the students can use these surfaces as design surfaces within an interval of solar irradiation and temperature universes. The array configuration is used to expand the power output range while the maximum power point surfaces are used to track and operate the PV array at its maximum power output [25]. 
TABLE 3: The PV powered PMDC motor GUI interface parameters.

\begin{tabular}{lcclcl}
\hline \multicolumn{2}{c}{ PV Array and PID controller } & \multicolumn{3}{c}{ PMDC Motor } \\
\hline Number of solar cells connected in series & $N_{s}$ & 10 & Resistance & $R_{m}$ & $1.5 \mathrm{Ohm}$ \\
Number of solar cells connected in parallel & $N_{p}$ & 10 & Inductance & $L_{m}$ & $0.00805 \mathrm{H}$ \\
Ambient temperature & $T$ & $20^{\circ} \mathrm{C}$ & Back emf constant & $K_{m}$ & $0.08 \mathrm{~V} \cdot \mathrm{s} / \mathrm{rad}$ \\
Ambient solar irradiation (\%) & $S$ & $100 \%$ & Viscous friction constant & $B_{m}$ & $7 \times 10^{-4} \mathrm{Nms} / \mathrm{rad}$ \\
Proportional constant & $K_{p}$ & 0.6 & Rotor moment of inertia constant & $J_{m}$ & $5 \times 10^{-4} \mathrm{~kg} \cdot \mathrm{m}^{2}$ \\
Integral constant & $K_{i}$ & 0 & Actual rated speed & $w_{n}$ & $1265 \mathrm{rad} / \mathrm{s}$ \\
Derivative constant & $K_{d}$ & 0 & Voltage source & $V_{m}$ & $300 \mathrm{~V}$ \\
\hline
\end{tabular}

TABLE 4: The PV powered AC load experiment parameters.

\begin{tabular}{|c|c|c|c|c|c|}
\hline \multicolumn{3}{|l|}{ PV array } & \multicolumn{3}{|l|}{ AC load } \\
\hline Number of solar cells connected in series & $N_{s}$ & 8 & Frequency & $f_{n}$ & $60 \mathrm{~Hz}$ \\
\hline Number of solar cells connected in parallel & $N_{p}$ & 1 & Nominal phase-phase voltage & $V_{n}$ & $208 \mathrm{~V}$ \\
\hline Ambient temperature & $T$ & $16^{\circ} \mathrm{C}$ & Active power & $P$ & $500 \mathrm{~W}$ \\
\hline \multirow[t]{2}{*}{ Ambient solar irradiation (\%) } & $S$ & $103 \%$ & Inductive reactive power & $Q_{L}$ & $200 \mathrm{VAR}$ \\
\hline & & & Capacitive reactive power & $Q_{C}$ & $500 \mathrm{VAR}$ \\
\hline \multicolumn{3}{|l|}{ Controller } & \multicolumn{3}{|l|}{ DC Load } \\
\hline Proportional constant & $K_{p}$ & 1 & Resistance & $R$ & $40 \mathrm{Ohm}$ \\
\hline Integral constant & $K_{i}$ & 0 & Inductance & $L$ & $0.0002 \mathrm{H}$ \\
\hline \multicolumn{3}{|l|}{ Filter } & \multicolumn{3}{|l|}{ Three-phase transformer } \\
\hline Resistance & $R_{f}$ & $0.05 \mathrm{Ohm}$ & Nominal power & $S$ & $1000 \mathrm{VA}$ \\
\hline Inductance & $L_{f}$ & $0.05 \mathrm{H}$ & Primary winding phase-phase voltage (rms) & $V_{1}$ & $208 \mathrm{~V}$ \\
\hline Capacitance & $C_{f}$ & $20 \times 10^{-6} \mathrm{~F}$ & Secondary winding phase-phase voltage (rms) & $V_{2}$ & $208 \mathrm{~V}$ \\
\hline
\end{tabular}

3.3. PV Array with a PMDC Motor Load. The VPVSL is tested under two loading conditions. First, a PMDC motor load is fed from the PV system. A PMDC motor is selected as the DC load in order to give an example of stand-alone DC load feeding. A controlled DC-DC chopper is used to control the voltage to DC loads. DC chopper is controlled for two different purposes, which are constant DC voltage operation and constant motor speed operation. The first one is to obtain a constant DC voltage at the output terminals of the DC-DC chopper in order to have a common DC bus. This operating condition gives the student the importance of common DC bus in distributed generation systems. The second purpose of controlling DC-DC chopper is for testing the system control to meet the load operating conditions. The motor is operated at a constant speed without considering a constant DC voltage. The purpose here is to operate the motor at constant speed whatever the voltage from PV array to DCDC chopper is. Therefore the second operating case shows the user how to eliminate the effects of the changes in solar irradiation and temperature levels on the load performance while the first case shows how the same effects are eliminated for the common DC bus voltage.

The GUI screen shown in Figure 5 is used with the sample case parameters given in Table 3 . The connection diagram, in Figure 5, includes a reverse current blocking diode (D), a current smoothing input filter $\left(R_{f}\right.$ and $\left.L_{f}\right)$, and a storage capacitor $\left(C_{f}\right)$ to overcome voltage discontinuities. A PID controlled type-D DC-DC chopper is used to adjust the voltage at load terminals.
The PID controller used in VPVSL generates the control signal, which is sent to a pulse width modulator (PWM) to generate the required switching pulses. For the two-quadrant DC-DC chopper, four pulses are generated.

The system outputs, which are observed, are shown in Figures 11, 12, 13, 14, 15, and 16. Figure 11 shows the controlled output voltage of DC-DC chopper. This voltage is kept constant considering that it is a voltage of common DC bus, which acts as a station to connect different power generating units together in a distributed power system. The speed variation of the PMDC motor load is given in Figure 12. For this operating case, the DC chopper is controlled to keep the speed constant. $I-V$ and $P-V$ characteristics of the PV system during the constant DC bus voltage operating condition are shown in Figures 13 and 14, respectively. Since there is no MPP tracking controller in the system, the operating point on $I-V$ and $P-V$ curves swings along the characteristics until it settles down at operating values that match the load side values. The operating voltage and power values can be seen clearly in Figures 15 and 16, in which the time responses of the PV array voltage and power are shown.

3.4. The PV Powered AC Load. The second loading condition of the VPVSL is a three-phase AC load. The connection diagram given in Figure 6 is used for the AC load operation. The connection scheme includes reverse current blocking diode (D) and input filter $\left(R_{f}, L_{f}\right.$, and $\left.C_{f}\right)$ for input current smoothing and input voltage continuity, a DC $R-L$ load for the system initiation, a PI controlled three-phase inverter, an 
TABLE 5: Assessment data student evaluations (Section-A).

(1) When I compare this experiment with other experiments belonging to this laboratory, this experiment is
Very easy (1)
Easy (2)
Reasonable (3)
Difficult (4)
Very difficult (5)

(2) When I compare this experiment with other experiments belonging to this laboratory, workload of this experiment is Too much (1)

Much (2)

Reasonable (3)

Few (4)

Too few (5)

(3) Experiment realization speed is Very fast (1)

Fast (2)

Reasonable (3)

Slow (4)

Very slow (5)

(4) This experiment is completely Very good (1)

Good (2)

Reasonable (3)

Inadequate (4)

Highly inadequate (5)

(5) This experiment instructor is completely

Very good (1)

Good (2)

Reasonable (3)

Inadequate (4)

Highly inadequate (5)

TABLE 6: Assessment data student evaluations using a Likert-scale (Section-B).

\begin{tabular}{ll}
\hline 6 & I understood the main idea \\
7 & Experiment coordination was very poor \\
8 & The experiment was attractive \\
9 & Experiment sheet (laboratory handout) was well arranged \\
10 & I learned something that I will remember future \\
11 & Experiment sheet helped me to comprehend orders effectively \\
12 & Using Matlab/Simulink GUI environment was good \\
13 & Using Matlab/Simulink GUI environment helped me to interpret the experiment results \\
14 & Using the model development of the system for Matlab/Simulink GUI environment enhanced my knowledge and skills \\
15 & I find the model development of the system for Matlab/Simulink GUI environment useful for learning related issue in \\
16 & Corresponding course \\
17 & Using the model development of the system for Matlab/Simulink GUI environment make me be more interested in this subject \\
18 & I was able to fully use the model development of the system for Matlab/Simulink GUI environment by following the instructions \\
19 & provided? \\
20 & It was difficult to gather from this experiment? \\
21 & Instructor showed effective control and guidance during the experiment \\
22 & How experiment will be done was explicitly explained in experiment sheet \\
23 & It was easy to attend the order since experiment sheet was well organized
\end{tabular}

Note: strongly agree: 1; agree: 2; neither agree or disagree: 3; disagree: 4; strongly disagree: 5 .

isolation transformer for filtering and isolation purposes, and a three-phase AC RLC load. The input parameters used in Figure 6 for the sample study case are given in Table 4 .

As mentioned earlier, the students or the users are able to plot and observe the voltage at the output terminals of the inverter, the voltage of the PV array under load, $I-V$ characteristics of the array under loading, the AC voltage at load terminals, PV array current under load and $P-V$ characteristics of the panel under loading conditions. The controller gains $\left(K_{P}, K_{I}\right)$ can be adjusted to provide the AC load demands (required voltage and frequency with minimum disturbances). PV array characteristics can also be observed from this operating process. The virtual experiment outputs are shown in Figures 17, 18, 19, 21, and 22. Figures 17 and 18 show the time variations of the PV array voltage and current, respectively. These two figures show the steady-state operating voltage and current of the array. The array voltage given in Figure 17 is the DC voltage converted to three-phase $\mathrm{AC}$ voltage by the inverter.

The output voltage of the inverter is given in Figure 19. Since the voltage at the output terminals of the inverter is not pure $\mathrm{AC}$, an isolation transformer is used as a filtering device to minimize the voltage harmonics so that the AC voltage waveform shown in Figure 20 is obtained with less harmonics.

$I-V$ and $P-V$ characteristics of the PV array are shown in Figures 21 and 22. After the initial swinging of the operating point on the curves, it settles down to steady-state operating values as depicted in Figures 17 and 18. The operating points of the PV array on $I-V$ and $P-V$ characteristics in Figures 21 and 22 are marked using the information from Figures 17 and 18. 


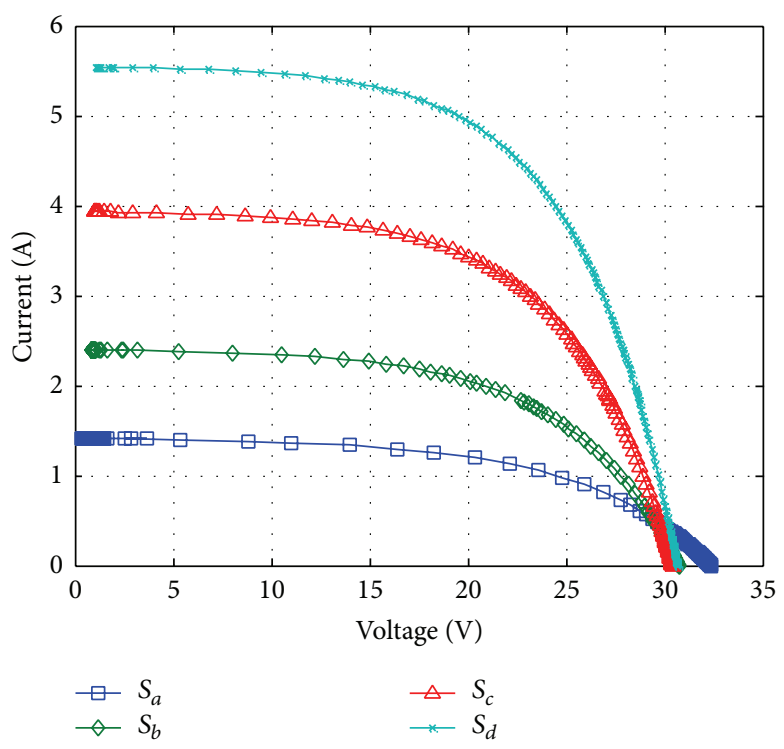

(a) $I-V$ characteristics

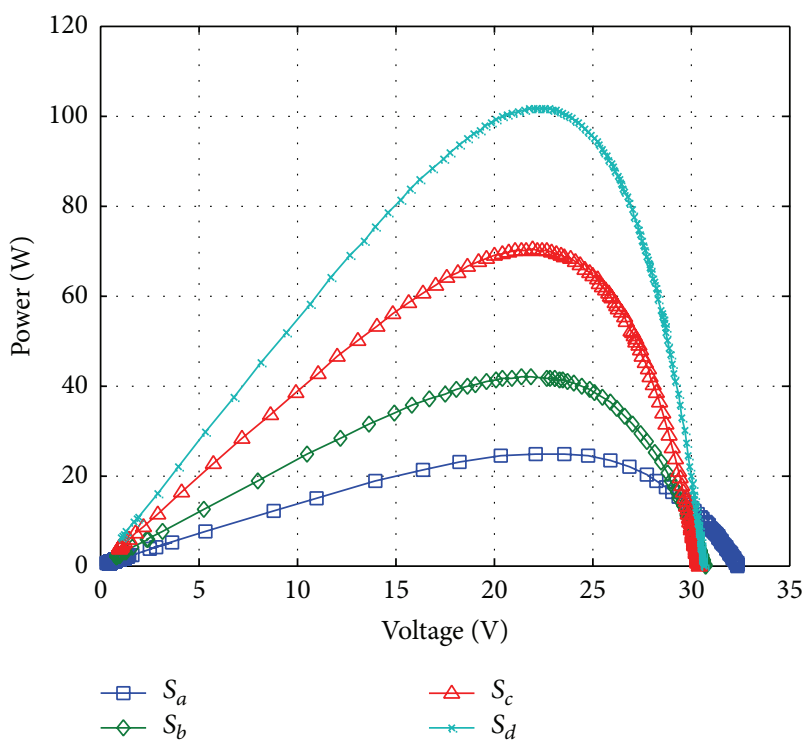

(b) $P-V$ characteristics

FIgURE 8: The effect of solar irradiation on $I-V$ and $P-V$ characteristics of the PV array.

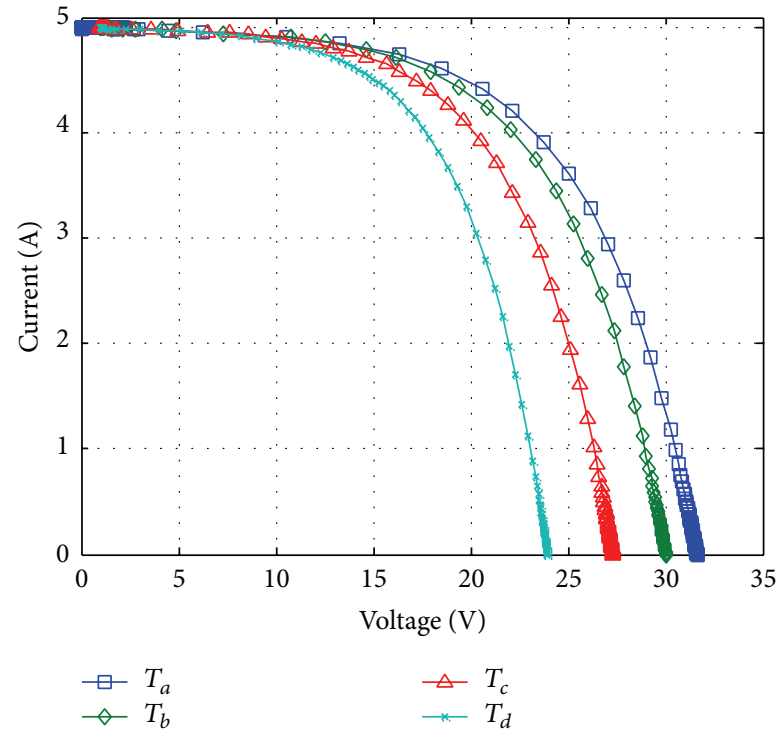

(a) $I-V$ characteristics

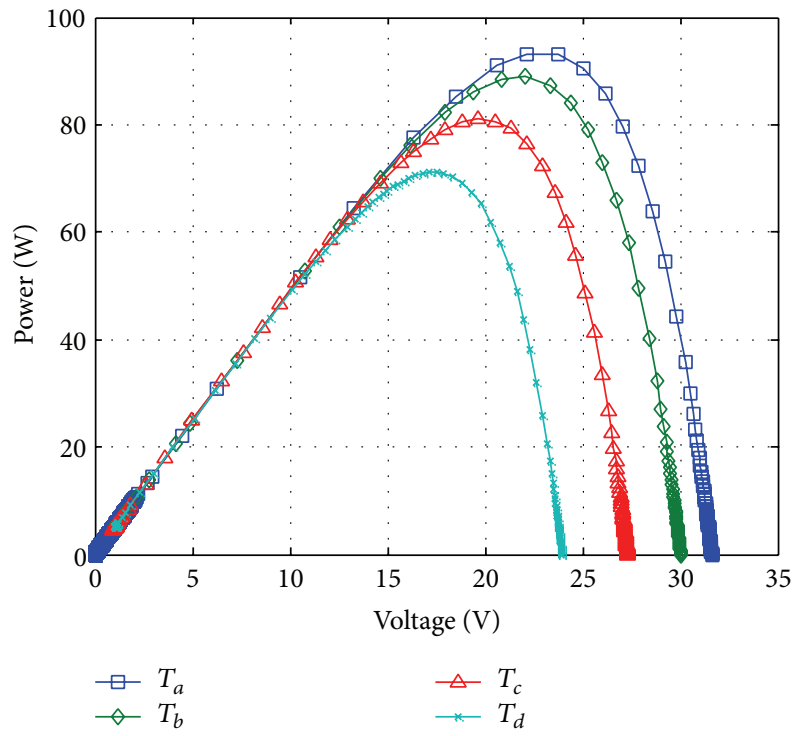

(b) $P-V$ characteristics

FIgURE 9: The effect of temperature on $I-V$ and $P-V$ characteristics of the PV array.

\section{Student Assessment and Evaluation}

The effectiveness of learning based on the GUI environment is determined by experiment report and questionnaire. The experiment report is based on the GUI interface explained thoroughly in the experiment sheet (laboratory handout). A questionnaire is an important source to observe the students' reactions. Individual students share their perceptions of the experiment. Thus, the students were asked to fill in a questionnaire about the experiment, characteristics of the environment, and opinion about instructor during experiment. The students can specify the pros and cons of the environment and experiment. The questionnaire consisted of thirty-three questions, as shown in Tables 5, 6, and 7. The questionnaire consists of three sections (Section-A, Section-B, and SectionC). We used Likert scales most commonly applied rating scales in spite of some limitations [26]. General opinion about experiment and instructor are roughly researched in Section-A. The students' observations and comments about effectiveness of the experiment and instructor are deeply taken on in Section-B and Section-C, respectively.

The students gave a grade between 5 (strongly disagree) and 1 (strongly agree) based on Likert Scale. The students' observations and comments given in Tables 5-7 are evaluated 


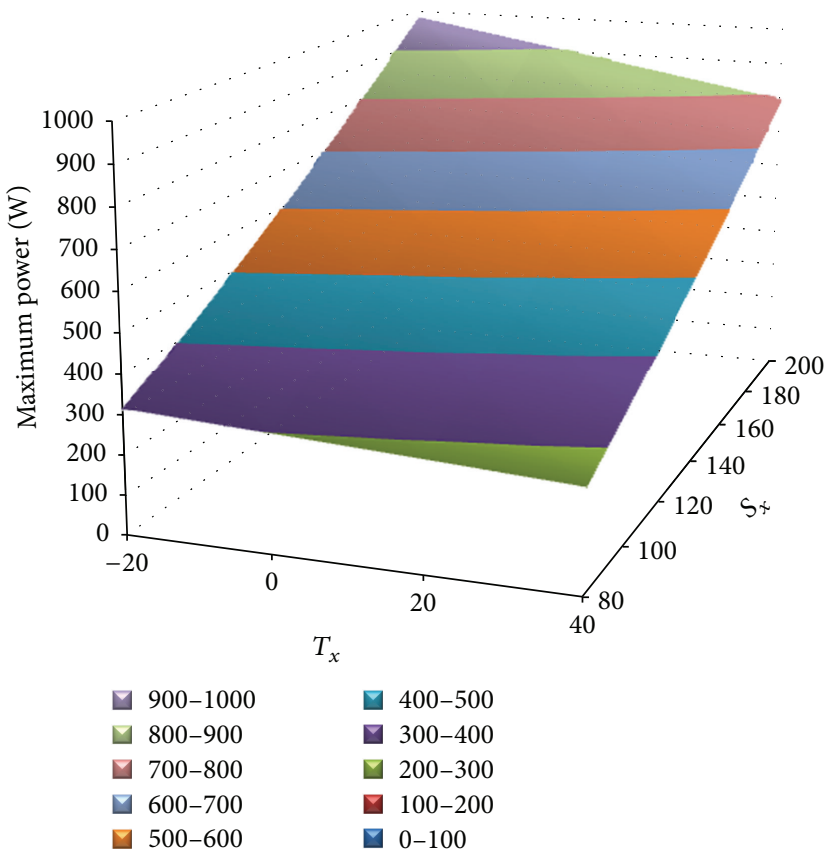

(a) Maximum power point surface

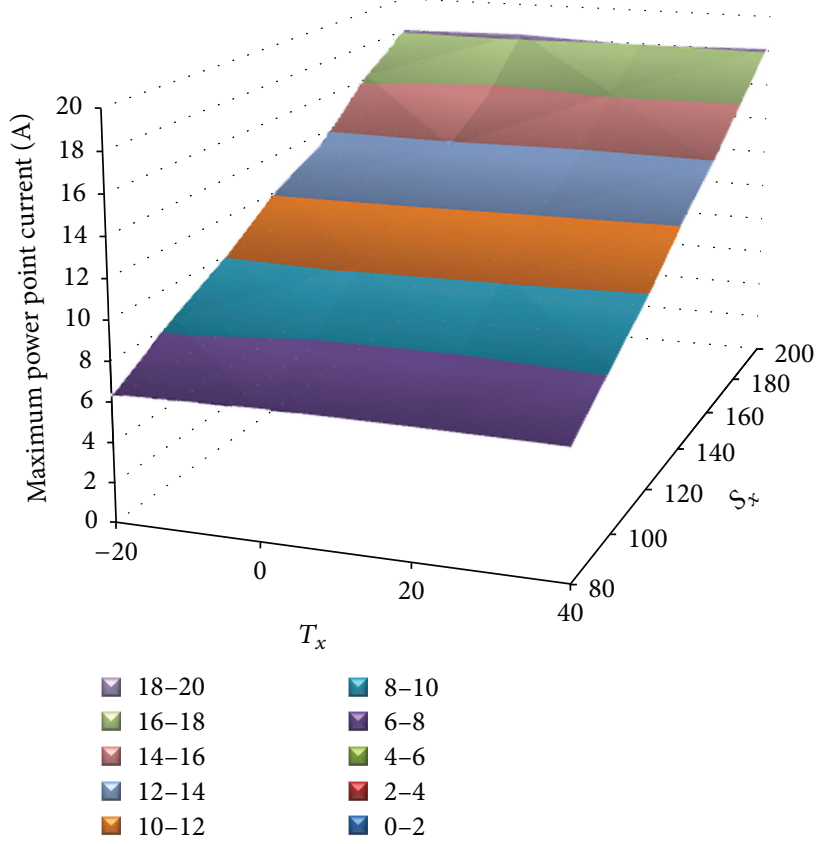

(b) Maximum power point operating current surface

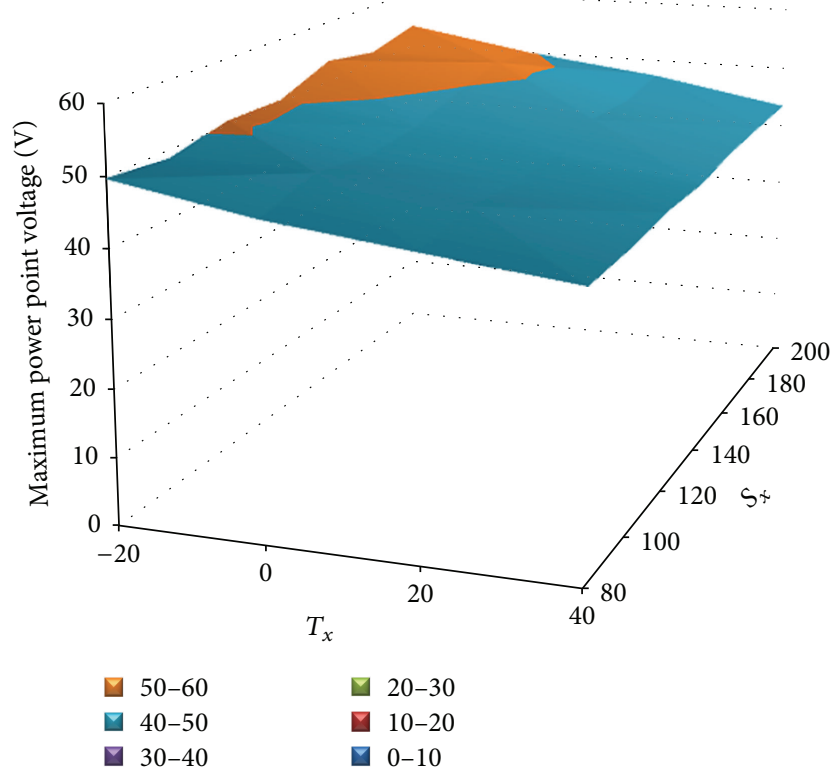

(c) Maximum power point operating voltage surface

Figure 10: Maximum power point surfaces under variable solar irradiation and temperature levels with fixed sizing. (a) Maximum power point surface, (b) maximum power point operating current surface and, (c) maximum power point operating voltage surface.

and their success based on their laboratory reports, due a week after the completion of the laboratory, is described in percentages for each group shown in Figure 23. The reports were marked according to experiment sheet (handout) explained above. The global result gotten from the questionnaire (average scores of each question) is shown in Figures 24, 25, and 26 and Table 8.

\section{Conclusion}

Design and utilization of a Virtual Photovoltaic Systems Laboratory for engineering undergraduate curriculum are introduced in this paper. The Virtual Photovoltaic System Laboratory described in this study is developed to teach students the basics and design steps of photovoltaic solar 
TABle 7: Assessment data student evaluations using a Likert-scale (Section-C).

\begin{tabular}{ll}
\hline 24 & Instructor was powerful communicator \\
25 & Instructor was eager to teach \\
26 & Instructor performance interacted with me \\
27 & Instructor explanation was explicit and fluent \\
28 & Instructor explanation complicated taking notes \\
29 & Instructor enabled me to concentrate more \\
30 & Instructor behavior was friendly and pleasant \\
31 & Instructor was well prepared \\
32 & Instructor was self-confident \\
33 & I do not ask for instructor help for other things \\
\hline
\end{tabular}

Note: strongly agree: 1; agree: 2 ; neither agree nor disagree: 3 ; disagree: 4 ; strongly disagree: 5 .

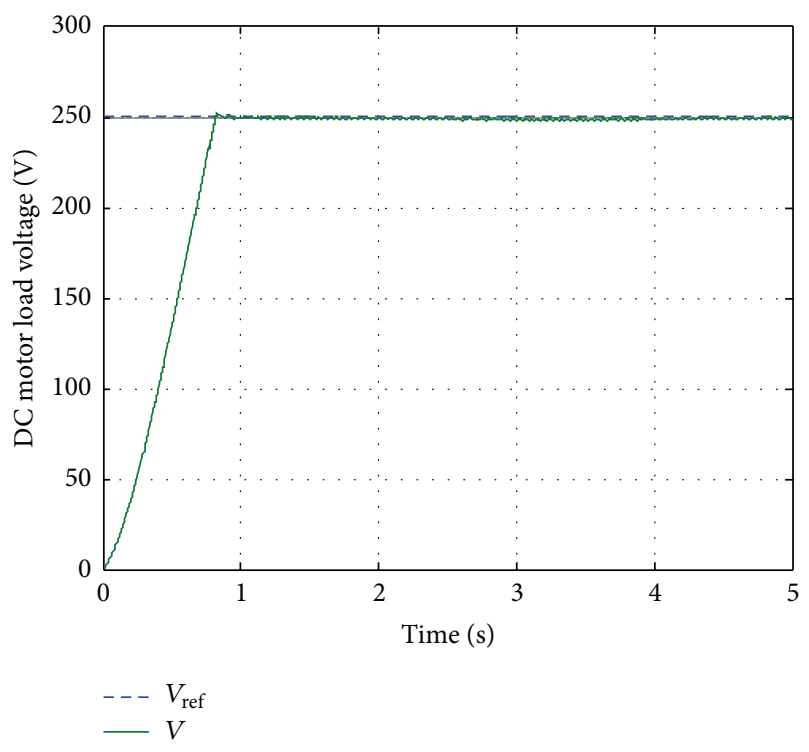

FIGURE 11: DC motor load voltage waveform.

energy systems in a virtual environment before entering the field. Proposed VPVSL offers five modules to the users. The first module can be used to analyze the $I-V$ and $P-V$ characteristics of PV systems based on sizing, solar irradiation, and temperature conditions. Module 1 provides a GUI window to the user to change solar irradiation level, temperature and the sizing parameters so that both design and the effects of the changing environmental conditions are set and analyzed. Module 2 can be used to analyze the effect of solar irradiation level under constant temperature and fixed sizing conditions. The effects of the changes in temperature can be analyzed using Module 3 under constant solar irradiation and fixed sizing conditions. The proposed system is tested under two loading conditions. Module 4 provides the testing GUI window for a PMDC motor load. A PID controller is included in this module along with a DC-DC chopper in order to have a constant DC voltage to be treated as a common DC bus, at which a PMDC motor is connected. Module 5 is used to test the VPVSL for AC loading. A three-phase inverter and

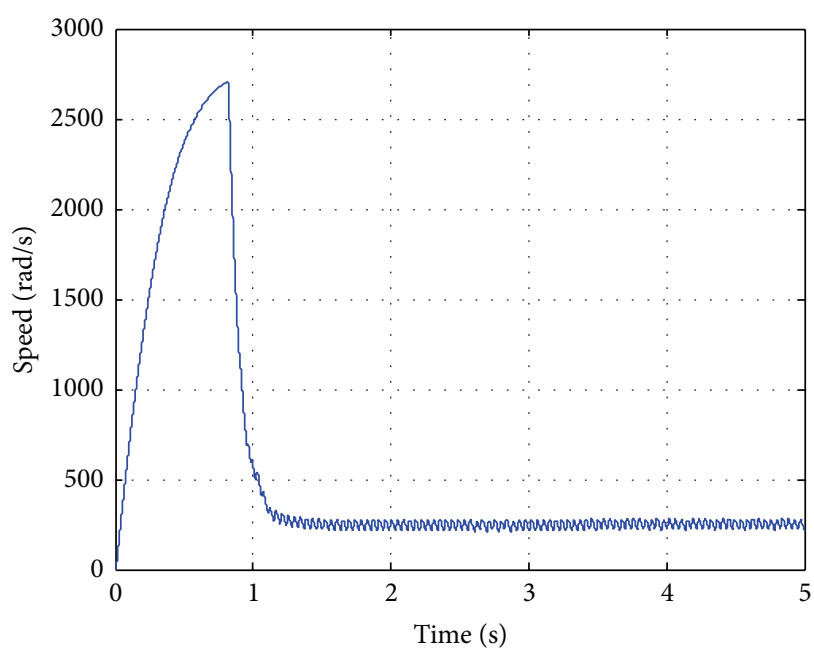

FIGURE 12: Speed-time waveform.

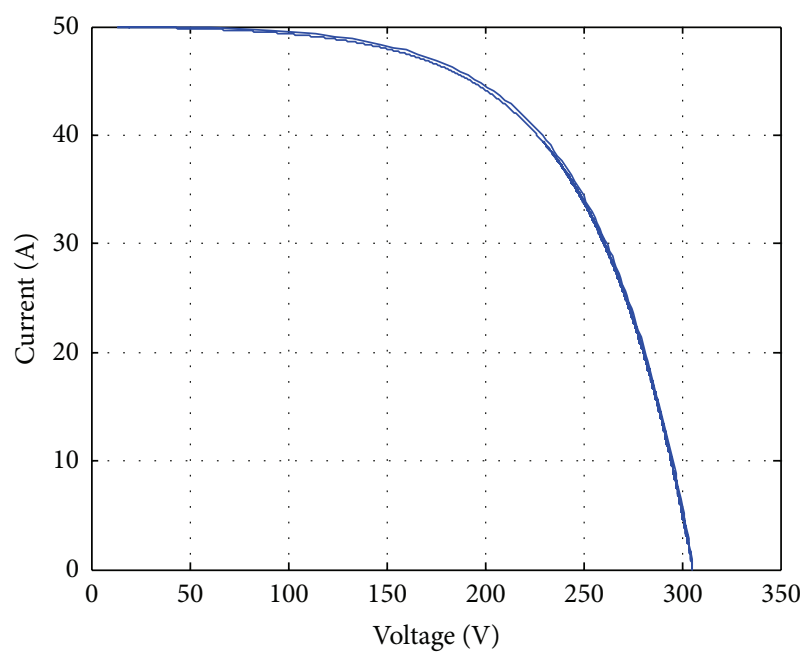

FIGURE 13: PV current-voltage waveform.

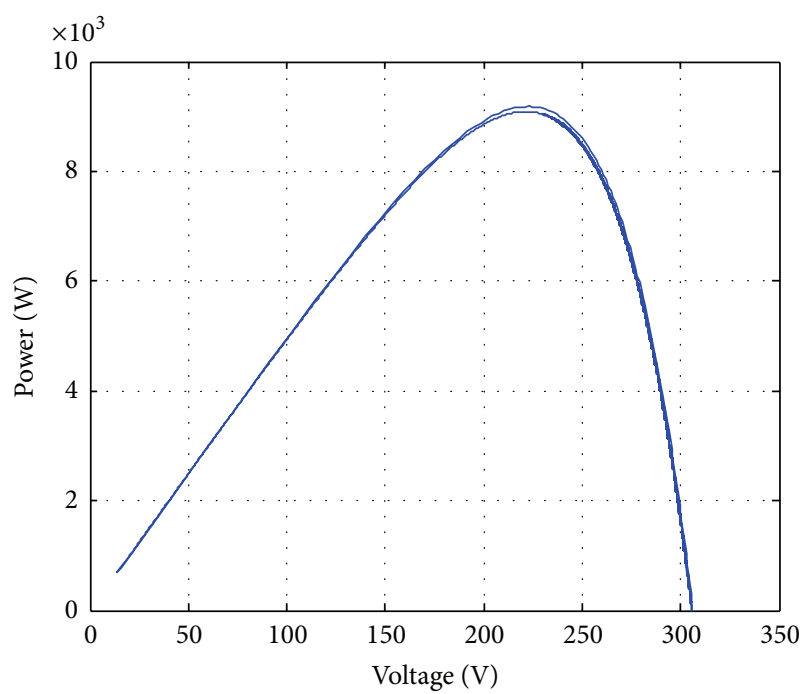

FIGURE 14: PV power-voltage waveform. 


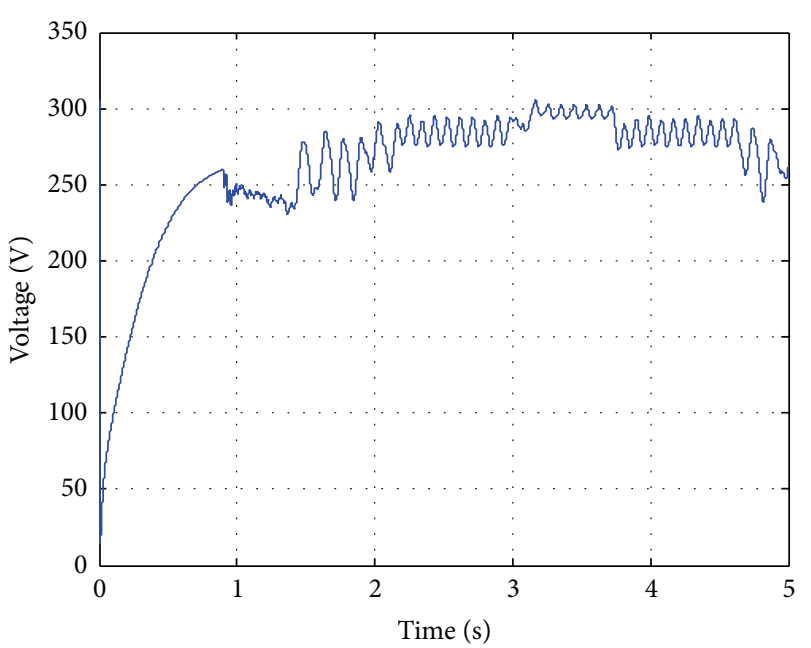

FIgURE 15: Variation of PV array voltage in time domain.

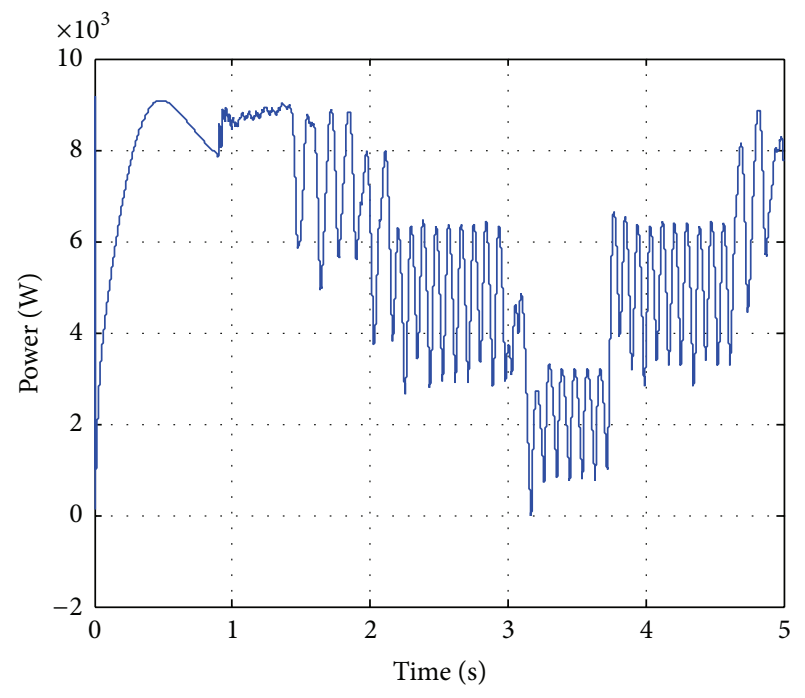

FIGURE 16: Variation of PV array power in time domain.

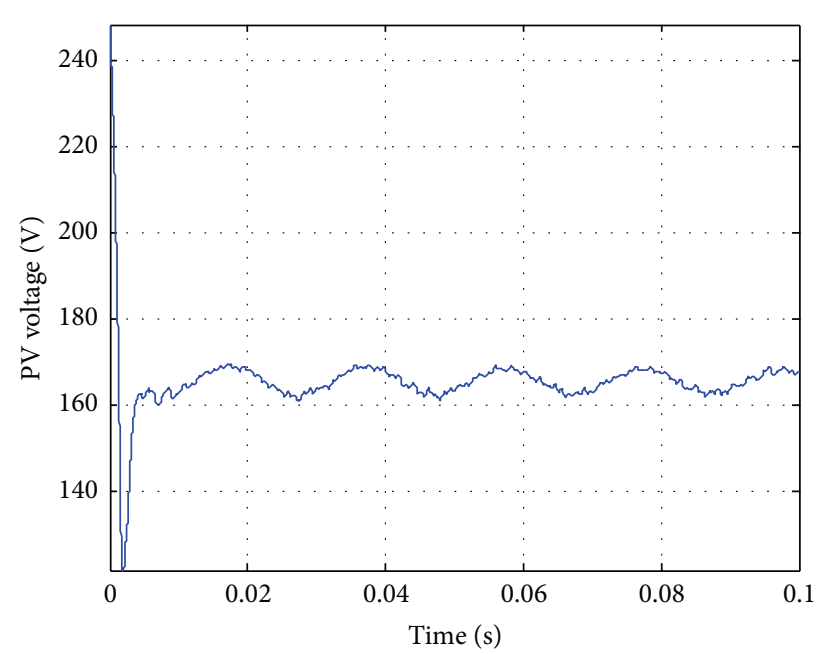

FIGURE 17: Load PV voltage waveform.

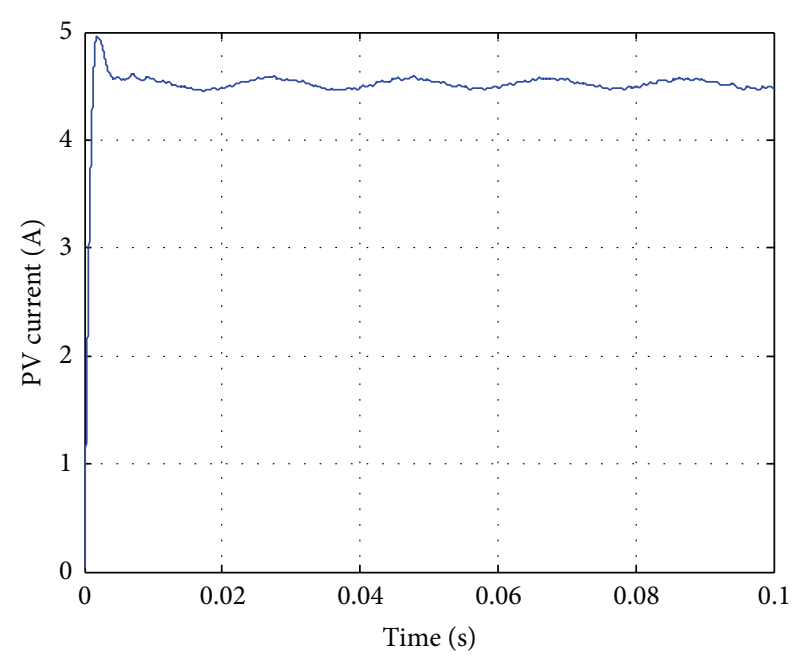

FIGURE 18: PV current waveform.

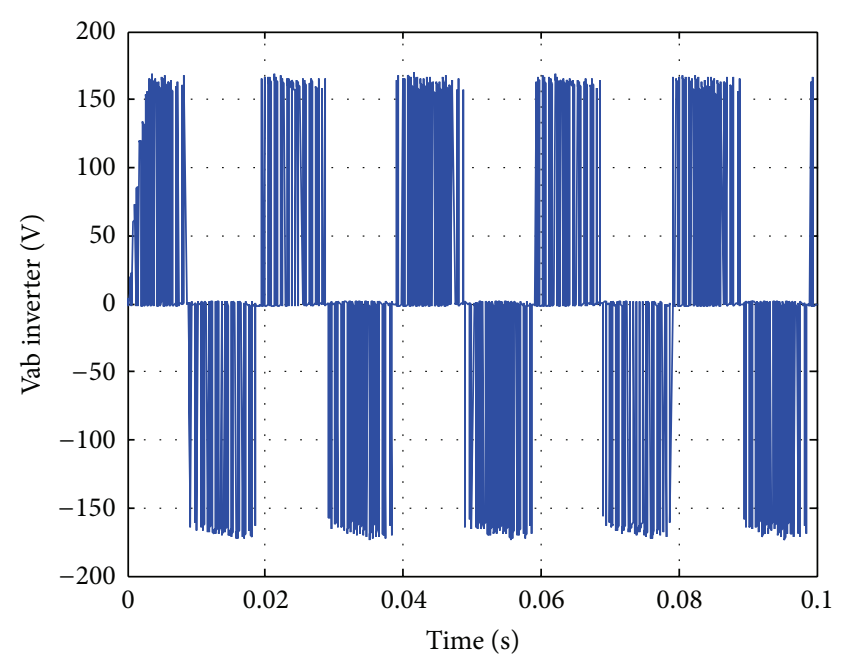

FIGURE 19: Inverter voltage waveform.

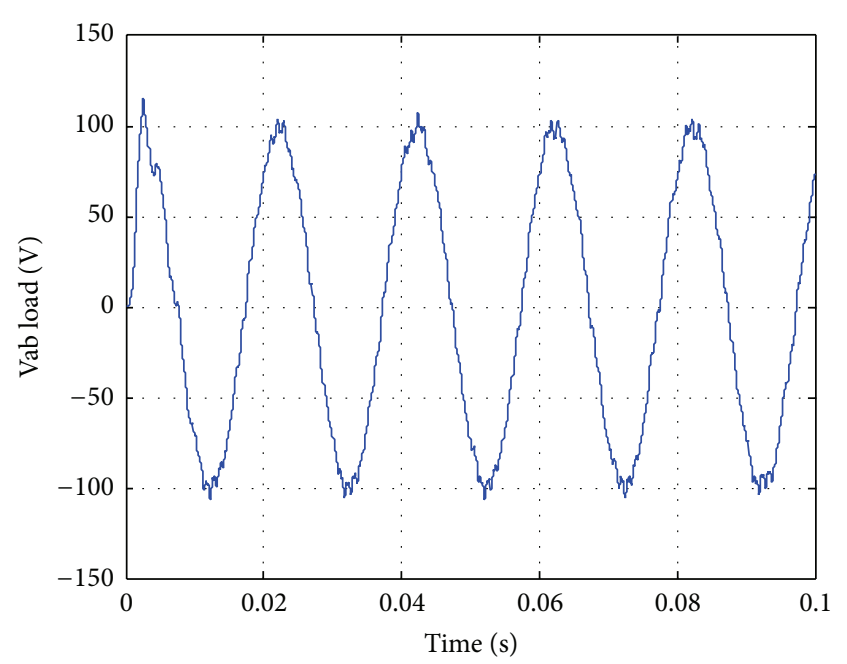

FIGURE 20: AC load voltage waveform. 


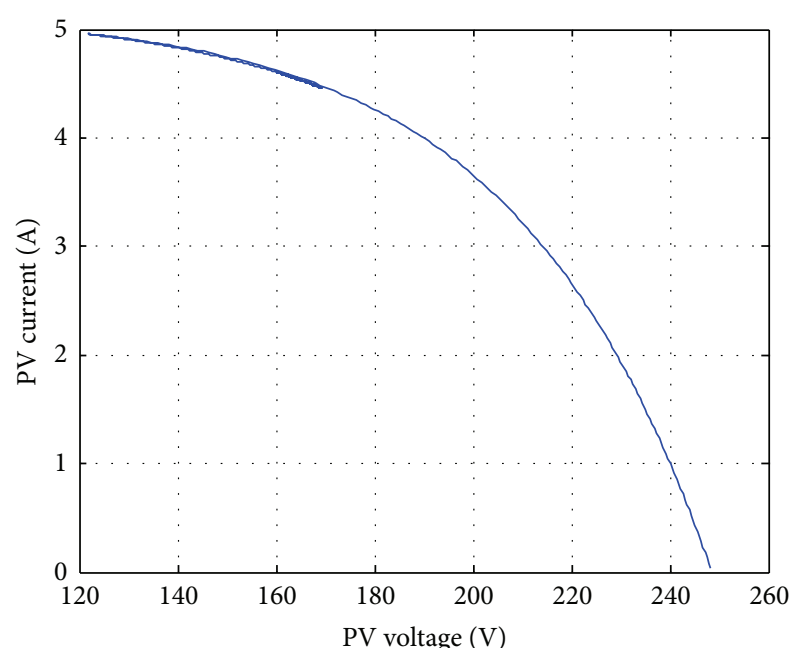

FIgURE 21: PV current-voltage waveform.

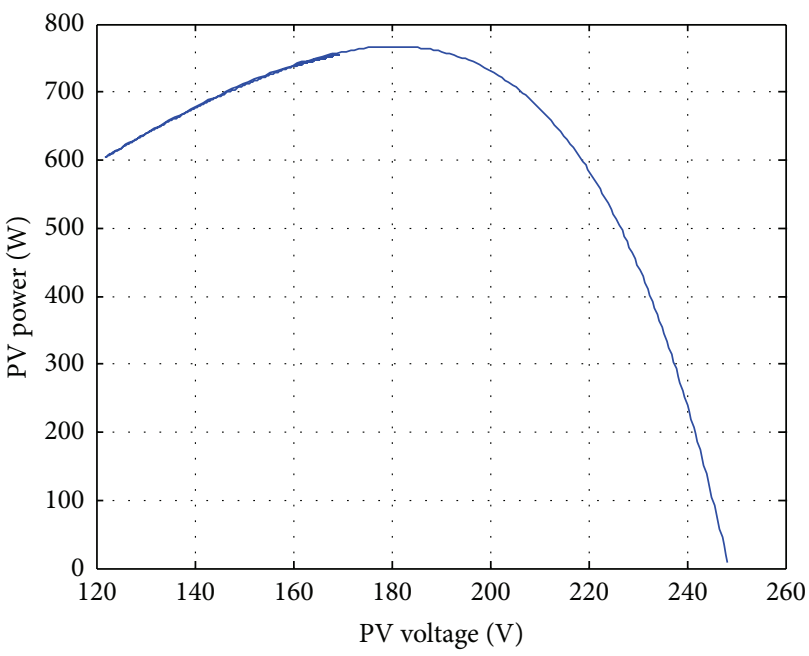

FIGURE 22: PV power-voltage waveform.

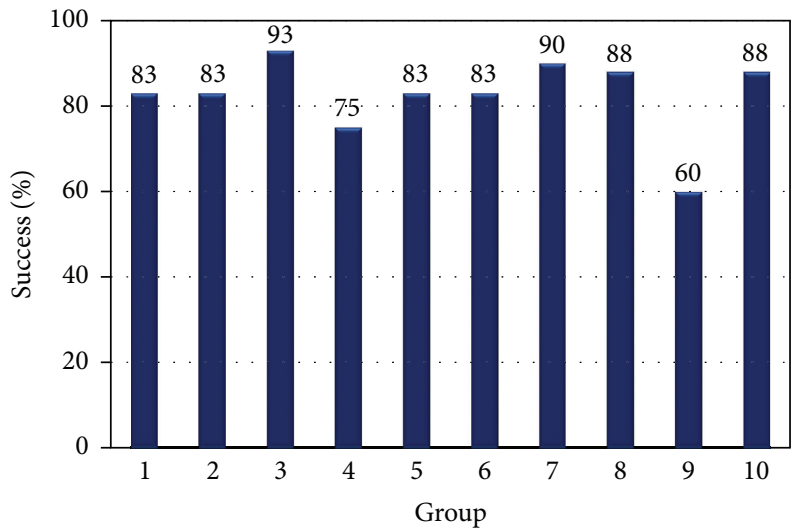

FIGURE 23: The group success in experiment in percentages.

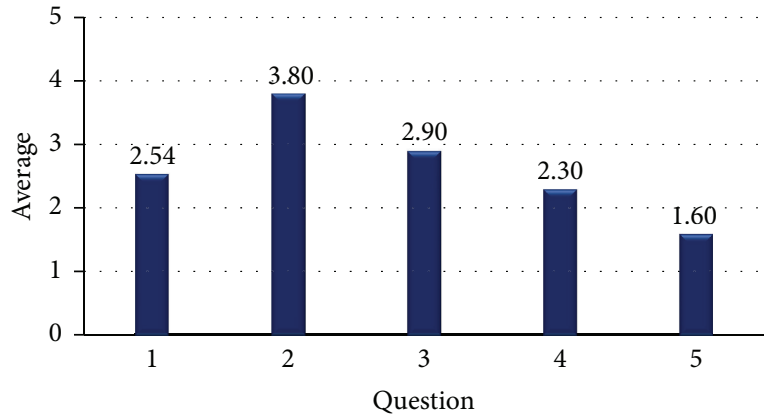

FIGURE 24: Summary of responses to student opinion survey (Section-A).

TABLE 8: Student evaluation results.

\begin{tabular}{lccccc}
\hline Question & SD (\%) & D (\%) & N (\%) & A (\%) & SA (\%) \\
\hline 6 & 2 & 2 & 6 & 46 & 44 \\
7 & 28 & 34 & 22 & 12 & 4 \\
8 & 2 & 4 & 18 & 44 & 32 \\
9 & 0 & 10 & 14 & 33 & 43 \\
10 & 0 & 6 & 4 & 56 & 34 \\
11 & 0 & 6 & 24 & 38 & 32 \\
12 & 2 & 4 & 6 & 32 & 56 \\
13 & 0 & 6 & 28 & 38 & 28 \\
14 & 0 & 12 & 28 & 32 & 28 \\
15 & 2 & 12 & 32 & 36 & 18 \\
16 & 0 & 8 & 24 & 34 & 34 \\
17 & 2 & 2 & 12 & 32 & 52 \\
18 & 8 & 12 & 14 & 40 & 26 \\
19 & 12 & 42 & 16 & 20 & 10 \\
20 & 0 & 6 & 8 & 34 & 52 \\
21 & 2 & 8 & 6 & 37 & 47 \\
22 & 2 & 4 & 10 & 40 & 44 \\
23 & 4 & 28 & 26 & 22 & 20 \\
24 & 0 & 0 & 2 & 37 & 60 \\
25 & 2 & 0 & 12 & 30 & 56 \\
26 & 2 & 0 & 14 & 42 & 42 \\
27 & 0 & 0 & 6 & 28 & 66 \\
28 & 32 & 38 & 22 & 2 & 6 \\
29 & 0 & 6 & 16 & 42 & 36 \\
30 & 2 & 0 & 0 & 18 & 80 \\
31 & 0 & 0 & 6 & 28 & 66 \\
32 & 0 & 4 & 20 & 74 \\
33 & 18 & 2 & 2 & 2 \\
\hline SD: strongly disagree, D: disagree, N: neutral, A: agree, SA: strongly agree.
\end{tabular}

a three-phase transformer are included in this module to supply power to an RLC load.

Virtual test results for sample cases are obtained and discussed in the paper. It has been shown that the proposed VPVSL can be used in designing and analyzing purposes. The students can analyze and understand the operational characteristics of the PV systems as well as being able to step in to the design stage of the PV systems. The proposed VPVSL 


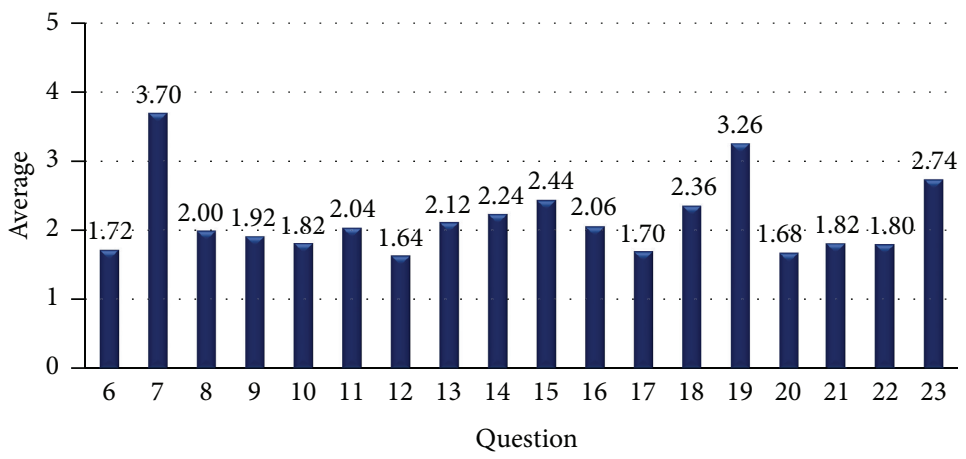

FIGURE 25: Summary of responses to student opinion survey (Section-B).

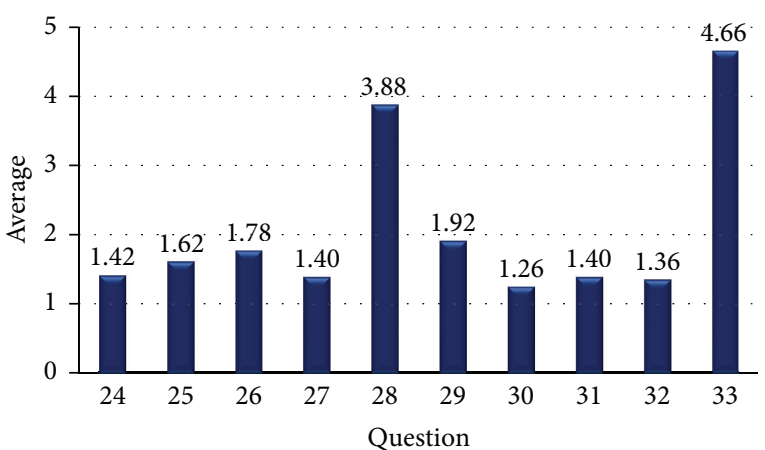

FIGURE 26: Summary of responses to student opinion survey (Section-C).

has been used in Power Systems Lab in the Department of Electrical and Electronics Engineering at Karadeniz Technical University as a part of undergraduate curriculum. A survey on the students who took the lab has been carried out and responses are included in this paper. The survey indicates that the students get benefit of using the lab. They found it usable, easy, and understandable.

A maximum power point tracker, a battery charging unit, and power conditioning filter circuit options can be added to this study to expand the scope of the virtual lab. A wind energy conversion module, a fuel cell module, and a small hydro module can also be added to this system to develop a general virtual renewable energy laboratory. Besides, the proposed VPVSL can be expanded to handle real time experiments remotely. However, if the VPVSL is combined with a real time measurement and experimental system, some additional components and software will be needed. In order to perform the real time experiments remotely, a communication link and a device on/off switching control software are required. In this case, the connection and data transferring speed will be important as well as the bandwidth of the communication channels to handle the density of coinciding user demands. Due to large size and additional research in a different area such as communication and networking, the idea of establishing a remote VPVSL is left for the future work and is not studied in this paper.

\section{Appendix}

\section{The Photovoltaic Cell Parameters}

$$
\begin{aligned}
& T_{C}\left({ }^{\circ} \mathrm{C}\right)=20 \\
& S_{C}(\%)=100 \\
& \beta_{T}=0.004 \\
& \gamma_{T}=0.06 \\
& T_{a}\left({ }^{\circ} \mathrm{C}\right)=20 \\
& \alpha_{S}=0.2 \\
& A=62 \\
& k\left(\mathrm{JK}^{-1}\right)=1.3806488 \times 10^{-23} \\
& e(\text { coulombs })=1.603 \times 10^{-19} \\
& I_{0}(\mathrm{~A})=0.01 \\
& R_{S}(\Omega)=0.02 .
\end{aligned}
$$

\section{Nomenclature}

PV: Photovoltaic

GUI: Graphical user interface

VPVSL: Virtual photovoltaic systems lab

PMDC: Permanent magnet DC

MPPT: Maximum power point tracker

$V_{C}: \quad$ Solar cell output voltage

A: $\quad$ Curve fitting constant used in solar cell $I-V$ characteristics

$k: \quad$ Boltzmann constant

$T_{C}: \quad$ Reference solar cell operating temperature

$e: \quad$ Electron charge

$I_{\mathrm{ph}}: \quad$ Solar cell photocurrent

$I_{0}$ : $\quad$ Diode reverse saturation current

$I_{C}: \quad$ Solar cell output current

$R_{S}: \quad$ Series resistance of solar cell equivalent circuit

$N_{S}: \quad$ Number of cells in series

$N_{P}$ : Number of cells in parallel

$C_{T V}: \quad$ Temperature dependent scaling factor of solar cell voltage

$\beta_{T}: \quad$ Temperature constant affecting solar cell voltage 
$T_{a}: \quad$ Reference ambient temperature

$T_{x}$ : Current values of ambient temperature

$C_{T I}$ : Temperature dependent scaling factor of solar cell current

$\gamma_{T}: \quad$ Temperature constant affecting solar cell current

$S_{C}: \quad$ Reference solar irradiation

$\alpha_{S}: \quad$ Solar irradiation constant

$S_{x}: \quad$ Current values of solar irradiation

$S_{C}: \quad$ Reference solar irradiation

$\beta_{S}$ : Effect of the solar irradiation on cell voltage

$C_{S V}$ : Solar irradiation dependent scaling factor of solar cell voltage

$C_{S I}$ : Solar irradiation dependent scaling factor of solar cell current

$\gamma_{S}: \quad$ Effect of the solar irradiation on photocurrent

$\Delta T_{C}:$ Temperature change due to changing solar irradiation level

$V_{C X}$ : Solar cell operating voltage

$I_{\mathrm{ph} x}$ : Solar cell operating photocurrent

$P_{\max }$ : Maximum power photovoltaic array

$I_{\text {mpp }}$ : Maximum power point current photovoltaic array

$V_{\text {mpp }}:$ Maximum power point voltage photovoltaic array

$I_{\mathrm{sc}}$ : Short circuit current photovoltaic array

$V_{\text {oc }}$ : Open circuit voltage photovoltaic array.

\section{Conflict of Interests}

The authors declare that there is no conflict of interests regarding the publication of this paper.

\section{References}

[1] M. Hashemipour, H. F. Manesh, and M. Bal, "A modular virtual reality system for engineering laboratory education," Computer Applications in Engineering Education, vol. 19, no. 2, pp. 305-314, 2011.

[2] B. Balamuralithara and P. C. Woods, "Virtual laboratories in engineering education: the simulation lab and remote lab," Computer Applications in Engineering Education, vol. 17, no. 1, pp. 108-118, 2009.

[3] J. A. Kypuros and T. J. Connolly, "Student-configurable, webaccessible virtual systems for system dynamics and controls courses," Computer Applications in Engineering Education, vol. 16, no. 2, pp. 92-104, 2008.

[4] R. Dormido, H. Vargas, N. Duro et al., "Development of a webbased control laboratory for automation technicians: the threetank system," IEEE Transactions on Education, vol. 51, no. 1, pp. 35-44, 2008.

[5] E. Tanyildizi and A. Orhan, "A virtual electric machine laboratory for effect of saturation of the asynchronous machine application," Computer Applications in Engineering Education, vol. 17, no. 4, pp. 422-428, 2009.

[6] E. Lindsay and M. Good, "The impact of audiovisual feedback on the learning outcomes of a remote and virtual laboratory class," IEEE Transactions on Education, vol. 52, no. 4, pp. 491$502,2009$.
[7] H. Rehman, R. A. Said, and Y. Al-Assaf, "An integrated approach for strategic development of engineering curricula: focus on students' design skills," IEEE Transactions on Education, vol. 52, no. 4, pp. 470-481, 2009.

[8] G. C. Goodwin, A. M. Medioli, W. Sher, L. B. Vlacic, and J. S. Welsh, "Emulation-based virtual laboratories: a low-cost alternative to physical experiments in control engineering education," IEEE Transactions on Education, vol. 54, no. 1, pp. 48-55, 2011.

[9] S. Azaklar and H. Korkmaz, "A remotely accessible and configurable electronics laboratory implementation by using LabVIEW," Computer Applications in Engineering Education, vol. 18, no. 4, pp. 709-720, 2010.

[10] C. Elmas and Y. Sönmez, "An educational tool for power electronics circuits," Computer Applications in Engineering Education, vol. 18, no. 1, pp. 157-165, 2010.

[11] A. See and A. J. Leong, "An advanced-automated system for equipotential field lines mapping utilizing motion control," Computer Applications in Engineering Education, vol. 19, no. 1, pp. 171-182, 2011.

[12] H. Y. Yamin, I. A. Altawil, A. F. Al-Ajlouni, and A. S. AlFahoum, "A new developed educational approach to improve conventional teaching methodology of the power electronics laboratory," Computer Applications in Engineering Education, vol. 19, no. 1, pp. 193-200, 2011.

[13] A. F. Al-Ajlouni, H. Y. Yamin, and B. Harb, "Effect of instructional software on achievement of undergraduate students in Digital Signal Processing," Computer Applications in Engineering Education, vol. 18, no. 4, pp. 703-708, 2010.

[14] E. S. Aziz, S. K. Esche, and C. Chassapis, "Content-rich interactive online laboratory systems," Computer Applications in Engineering Education, vol. 17, no. 1, pp. 61-79, 2009.

[15] T. Yigit and C. Elmas, "An educational tool for controlling of SRM," Computer Applications in Engineering Education, vol. 16, no. 4, pp. 268-279, 2008.

[16] J. R. R. Ruiz, A. G. Espinosa, and J. A. Ortega, "Validation of the parametric model of a DC contactor using Matlab-Simulink," Computer Applications in Engineering Education, vol. 19, no. 2, pp. 337-346, 2011.

[17] J. A. Calvo, M. J. Boada, V. Díaz, and E. Olmeda, "SIMPERF: SIMULINK based educational software for vehicle's performance estimation," Computer Applications in Engineering Education, vol. 17, no. 2, pp. 139-147, 2009.

[18] I. Colak, S. Demirbas, S. Sagiroglu, and E. Irmak, "A novel web-based laboratory for DC motor experiments," Computer Applications in Engineering Education, vol. 19, no. 1, pp. 125-135, 2011.

[19] J. R. R. Ruiz, A. G. Espinosa, and X. A. Morera, "Electric field effects of bundle and stranded conductors in overhead power lines," Computer Applications in Engineering Education, vol. 19, no. 1, pp. 107-114, 2011.

[20] E. Aziz, "Teaching and learning enhancement in undergraduate machine dynamics," Computer Applications in Engineering Education, vol. 19, no. 2, pp. 244-255, 2011.

[21] I. H. Altas and A. M. Sharaf, "A photovoltaic array simulation model for matlab-simulink GUI environment," in Proceedings of the International Conference on Clean Electrical Power (ICCEP '07), pp. 341-345, Capri, Italy, May 2007.

[22] Criteria for Accrediting Engineering Programs: Effective for Reviews during the 2012-2013 Accreditation Cycle, ABET Engineering Accreditation Commission, 2011. 
[23] M. Buresch, Photovoltaic Energy Systems Design and Installation, McGraw-Hill, New York, NY, USA, 1983.

[24] I. H. Altas and A. M. Sharaf, "A fuzzy logic power tracking controller for a photovoltaic energy conversion scheme," Electric Power Systems Research, vol. 25, no. 3, pp. 227-238, 1992.

[25] I. H. Altas and A. M. Sharaf, "A novel on-line MPP search algorithm for PV arrays," IEEE Transactions on Energy Conversion, vol. 11, no. 4, pp. 748-754, 1996.

[26] D. R. Hodge and D. F. Gillespie, "Phrase completion scales: a better measurement approach than Likert scales?" Journal of Social Service Research, vol. 33, no. 4, pp. 1-12, 2007. 

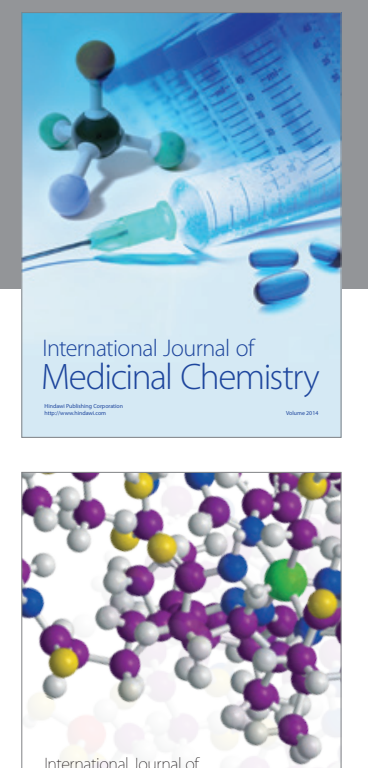

\section{Carbohydrate} Chemistry

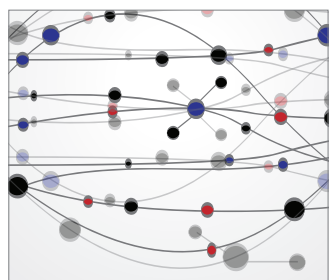

The Scientific World Journal
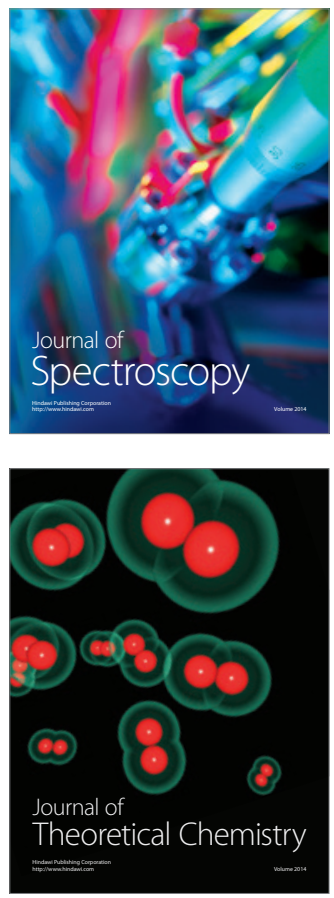
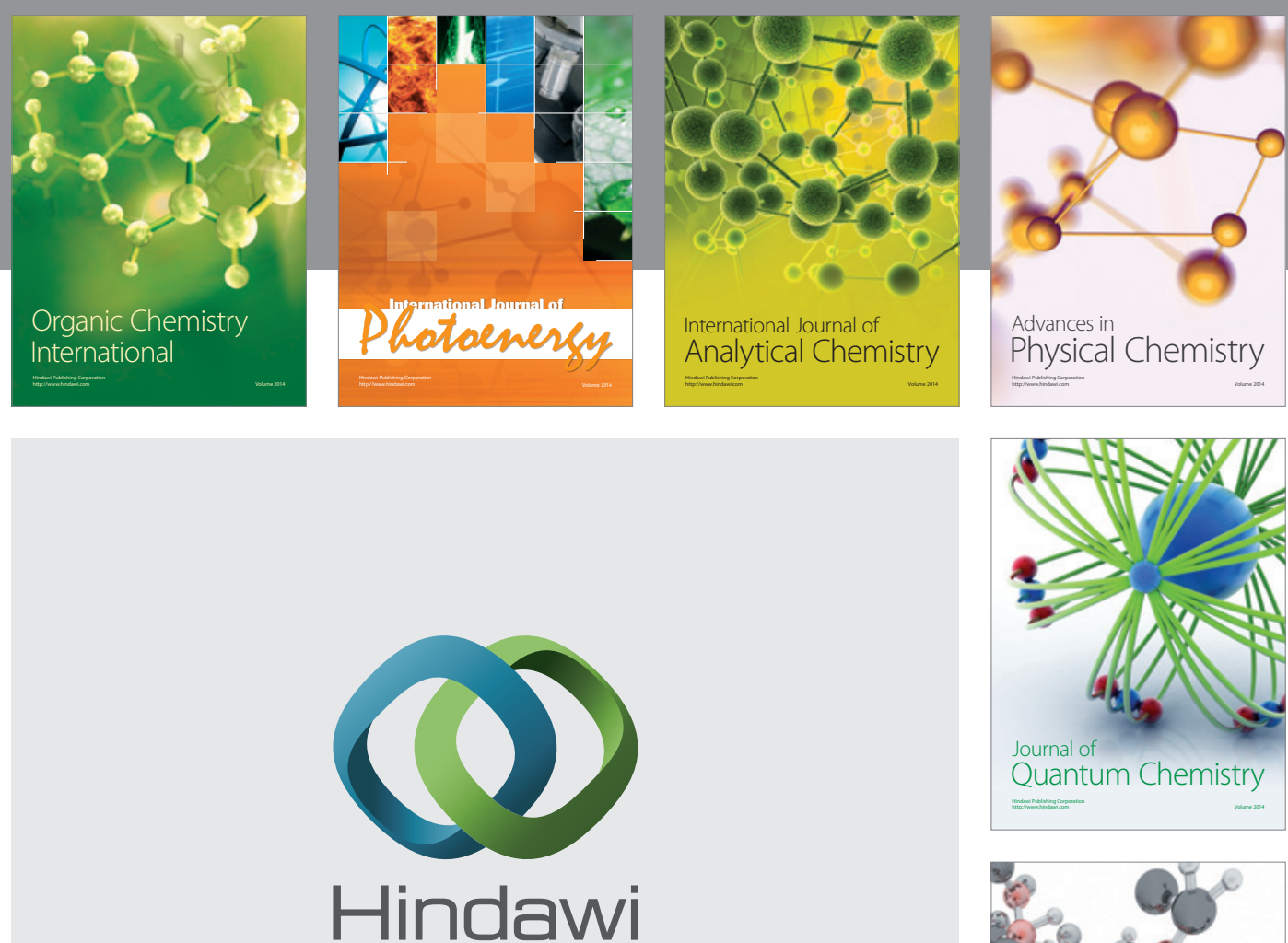

Submit your manuscripts at

http://www.hindawi.com

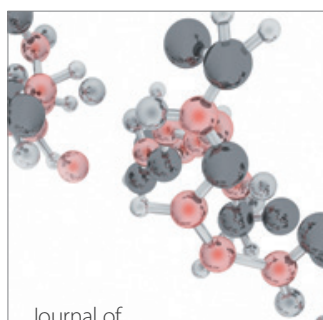

Analytical Methods

in Chemistry

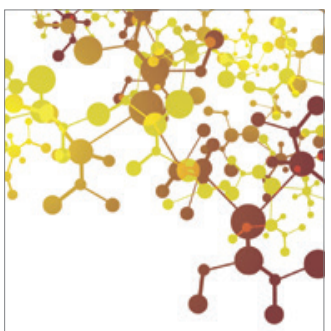

Journal of

Applied Chemistry

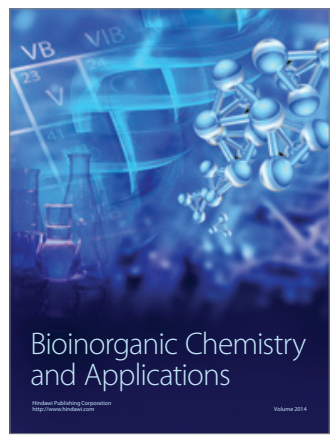

Inorganic Chemistry
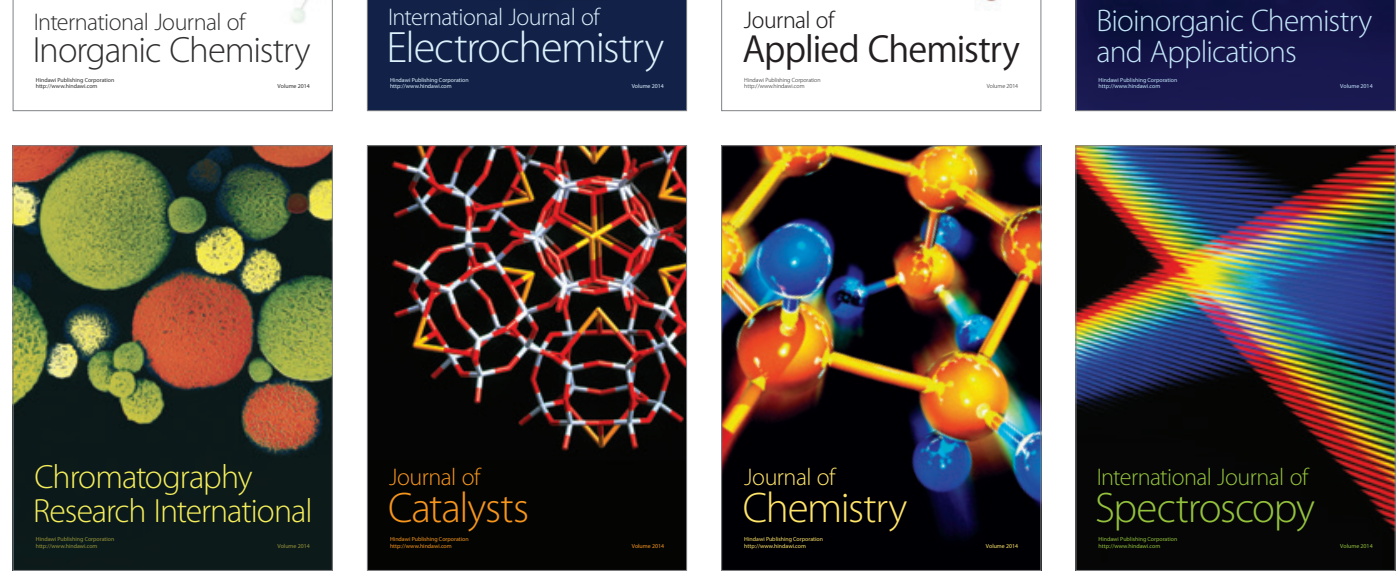